This item was submitted to Loughborough's Research Repository by the author.

Items in Figshare are protected by copyright, with all rights reserved, unless otherwise indicated.

\title{
Selective enzymatic modification of wool/polyester blended fabrics for surface patterning
}

PLEASE CITE THE PUBLISHED VERSION

https://doi.org/10.1016/j.jclepro.2018.11.079

PUBLISHER

(C) Elsevier Ltd.

VERSION

AM (Accepted Manuscript)

PUBLISHER STATEMENT

This paper was accepted for publication in the journal Journal of Cleaner Production and the definitive published version is available at https://doi.org/10.1016/j.jclepro.2018.11.079.

LICENCE

CC BY-NC-ND 4.0

\section{REPOSITORY RECORD}

Prajapati, Chetna, Edward Smith, Faith Kane, and Jinsong Shen. 2019. "Selective Enzymatic Modification of Wool/polyester Blended Fabrics for Surface Patterning”. figshare. https://hdl.handle.net/2134/36492. 
Selective enzymatic modification of wool/polyester blended fabrics for

surface patterning Chetna D Prajapati ${ }^{a+}$, Edward Smith ${ }^{a}$, Faith Kane ${ }^{b}$ and

Jinsong Shen ${ }^{a *}$

${ }^{a}$ Textile Engineering and Materials (TEAM) Research Group, School of Design, De Montfort University, Leicester, UK

${ }^{\mathrm{b}}$ Textile Design Research Group, School of the Arts, English and Drama, Loughborough University, Loughborough, UK

* Corresponding author: Textile Engineering and Materials (TEAM) Research Group, School of Design, De Montfort University, Leicester, LE1 9BH, UK.

Email: jshen@dmu.ac.uk; Tel:+44-1162577558

${ }^{\mathrm{b}}$ Present address: School of Design, College of Creative Arts, Massey University, Wellington, 6140, New Zealand.

+ Present address: Textile Design Research Group, School of the Arts, English and Drama, Loughborough University, Loughborough, UK 


\section{Highlights}

- Control of enzymatic hydrolysis of wool fibre component in blended fabrics.

- Enzymatic modification of wool blended fabrics to impart surface patterning.

- Surface patterning bioprocess to achieve similar effects to devoré.

- Biotechnology-based techniques with potential economic and environmental benefits. 


\title{
Selective enzymatic modification of wool/polyester blended fabrics for surface patterning
}

\begin{abstract}
An enzyme-based process was investigated to achieve surface patterning of fabrics as an alternative to conventional chemical processes. In the current study, the enzyme protease was employed to selectively modify a wool/polyester blended fabric to impart decorative surface effects. Controlled protease processing of the blended fabric dyed with Lanasol Blue CE enabled the degradation and removal of the dyed wool fibre component from the fabric blend, resulting in novel fading and differential fabric relief due to degradation of wool, revealing the undyed polyester component after enzyme treatment. A $38.5 \%$ weight loss was achieved, therefore $86.5 \%$ of the wool in the $45 / 55 \%$ wool/polyester blended fabric was removed from the structure. The activity of protease is highly specific, therefore, it caused no damage to the polyester component. The control studies led to the development of surface pattern designs using the enzyme process, achieving effects similar to current processes such as devoré and discharge printing. This novel enzyme process permits the replacement of harsh chemicals used in current surface patterning processes with small doses of biodegradable enzymes.
\end{abstract}

\section{Keywords}

Enzyme, Polyester, Protease, Surface pattern, Wool

\section{Introduction}

Growing environmental concerns, legal restrictions on chemical use and an increase in scientific knowledge has led to the textile industry to pursue and develop enzyme-based processing as an alternative to conventional chemical based processes for textile wet processing. Enzyme-based textile wet processing methods such as desizing, bio-scouring, bio-polishing and bleach clean-up have already become well established in the textile industry (Araújo et al., 2008; Shen and Smith, 2015). The adoption of enzymatic approaches has offered processes with improved environmental sustainability by eliminating inherent drawbacks associated with chemical processing that involve heavy use of water, energy and chemicals resulting in hazardous waste (Nielsen et al., 2009). Enzymes are highly specific biocatalysts that can operate under mild processing conditions, therefore, reducing not only the consumption of chemicals, energy and water, but also the subsequent generation of effluent waste. Furthermore, enzymes are biodegradable and offer the possibility of recycling, leading to the potential of closed loop processes.

Proteolytic enzymes have been investigated for incorporation in wool processing for improving scouring efficiency, handle properties, and imparting shrink resistance (Shen, 2010). Proteolytic 
enzymes promote the hydrolysis of proteins, therefore breaking down the cuticle scales on the wool fibre surface. However, if not carefully controlled this enzymatic process can cause significant damage to the wool fibre due to the enzyme penetrating into and attacking the fibre core (Nolte et al., 1996; Shen et al., 1999), resulting in high strength and weight loss (Bishop et al., 1998). To restrict the enzyme attack to the cuticle scales and prevent damage to the fibre, methods of either modifying the treatment process using enzymes with wool-extracted polypeptides (Smith and Shen, 2011), pretreatment with cetyltrimethylammonium bromide (Smith and Shen, 2012) or biopolymer chitosan (Vilchez et al., 2005; Vilchez et al., 2008) have been investigated. Other studies have explored enlarging the proteolytic enzyme by chemical modification using various enteric copolymers of varied molecular masses and chemical structures (Silva et al., 2006; Smith et al., 2008; Smith et al., 2010), or by genetic modification (Araújo et al., 2009) for the same effects. Large scale trials conducted by Shen et al. (2007) using chemically modified proteases, demonstrated the ability to control proteolytic attack on wool could lead to the successful development and application of enzymatic treatments for varying finishing effects for wool fabrics such as shrink-resistance. However, a viable commercial process is not currently available due to the fact that the use of this group of enzymes can result in unpredictable, difficult to control reactions, leading to unacceptable fibre damage, and chemically modified proteases are currently not cost effective.

Although, many studies look to restrict the access of enzyme to the surface of the wool fibre, surface modification or controlled degradation of wool fibres through enzymatic treatment present clear opportunities that could be exploited for aesthetic design purposes, potentially leading to innovative decorative textile effects and finishes. If reaction parameters are controlled, subtle relief and coloration effects similar to fading, bleaching, devoré ("burn-out") or discharge printing could possibly be achieved through the removal of selected fibres from wool and wool blended fabrics. Textile patterning processes such as devoré and discharge printing are simple and inexpensive methods for generating surface pattern on fabrics with the application of a chemical paste. These styles have remained popular and significant since first introduced because the effects obtained from these processes are often different and aesthetically superior to direct screen printing styles (Miles, 1994) and digital textile printing.

Devoré typically involves printing a chemical paste on a fabric to destroy fibre in an area of a predetermined pattern either forming "designed" holes in single fibre fabrics or for blended fabrics destroying one fibre while leaving the other fibre undamaged to produce lace-like, or relief and etched patterned fabrics. The printing paste contains an agent that is capable of dissolving or destroying the fabric in the areas printed during subsequent processing, where the fabric is heated with steam or dry heat, followed by washing. Blended fabrics treated by devoré usually contain fibre components that possess opposite properties to each other, in which one fibre component is chemically vulnerable to the 
paste while the other fibre component is chemically resistant (Kinnersly-Taylor, 2003; Wells, 2000). The chemical paste varies in nature according to the fibres used in the construction of the fabric. To destroy the protein fibre component in protein fibre blended fabrics such as wool/polyester, wool/acrylic, wool/cellulosic or silk/polyester, a print paste containing a strong alkali such as sodium hydroxide often at a ratio of 25:40 alkali to thickener is printed onto the fabric then steamed at atmospheric pressure for up to 45 minutes, or pressure steamed at 100 p.s.i. for 10 minutes (KinnerslyTaylor, 2003; Wells, 2000). To remove the cellulose component in cellulose blends a strong acid paste is used.

Devoré fabric is popular for both fashion and furnishing textiles with new variations of devoré appearing in collections every few years (Watkins, 2017). However, the chemical processing method of creating coloured patterned fabrics by removing selected fibres from constructed fabrics through the application of either a strong acid or alkali followed by dry-heat (Fulton, 1908; Maertens, 1886) or steaming (Timme, 1902) process has not changed much since its inception at the beginning of the $20^{\text {th }}$ century (Robertson, 2006).

In discharge printing, surface pattern is produced by the chemical destruction of the original dye in the printed areas enabling the creation of a negative image, a white or a coloured pattern on a dark background. The process requires the fabric to be dyed first with dyes that can be discharged (destroyed) by selected discharging pastes, usually consisting of oxidising or reducing agents, acids, alkalis or salts (Miles, 1994). The discharge paste is printed onto the dyed fabric, and during the subsequent steaming process the dye in the patterned area is discharged to either produce a white discharge (colour free) or a coloured discharge (illuminating style), where a discharge resistant dye is incorporated into the printing paste, so that the discharge and coloration occurs simultaneously during the steaming fixation stage. The choice of discharging agents and the strength of paste required for optimum discharge effects is largely determined by the class of dye to be discharged, the depth of shade of the dyed fabric, and the fibre being printed. Pastes often contain up to a ratio of 2:10 discharging agent to thickener formulations (Miles, 1994). Commercially, the most widely used discharging agents are sulphoxilic acid derivatives: sodium formaldehyde sulphoxylate (Rongalit C® (BASF) or Formosul), zinc formaldehyde sulphoxylate (Decrolin ${ }^{\circledR}(B A S F)$ ) and calcium formaldehyde sulphoxylate (Rongalit $\mathrm{H} \circledast$ (BASF)), of which the latter two are most suitable for protein fibres. Reducing agents need to be carefully selected, as in some cases unwanted fibre damage and discolouring may occur (Kinnersly-Taylor, 2003).

Both devoré and discharge printing are effective processes for producing patterned textiles, however, both processes require the use of either strong alkalis such as sodium hydroxide or reducing agents, in addition, to chemical auxiliaries to improve printing effects. The heavy use of these compounds can be toxic and hazardous to handle, and generate effluents that are difficult to treat and damaging towards the environment (Lacasse and Baumann, 2012; Makarov et al., 1999). The use of oxidising and reducing 
agents can also cause wool fibre damage, shrinkage and yellowing, all of which can be prevented or lessened with the addition of further chemical assistants to processing pastes (KinnerslyTaylor, 2003; Wells, 2000). Degradation of fibres using the devoré process occurs at a temperature around $200^{\circ} \mathrm{C}$ $\left(392^{\circ} \mathrm{F}\right)$, generating harmful fumes, therefore requiring the process to be carried out in controlled environments (Clarke, 2011).

As the textile industry moves towards more environmentally sustainable production, new innovative techniques for textile surface decoration are sought after. Laser processing has been suggested as an alternative to achieve devoré effects (Payne, 2010; Stoyel, 2007) although not achieved on an industrial scale. The use of enzymes as innovative biotechnology-based textile design tools for textile surface pattern could offer attractive alternatives to traditional and existing patterning techniques and production methods with potential economic, social and environmental benefits. At present, the potential for proteolytic enzymes to be used for the generation of decorative surface pattern remains relatively unexplored (Prajapati, 2016; Shen and Smith, 2015). Enzymatic wool hydrolysis could offer a simpler, cleaner and safer alternative processing method, principally eliminating or reducing the use of conventional reducing and/or oxidising agents, chemical auxiliaries and elevated temperatures for processing. The precise reaction specificity of an enzyme could be used for specific or targeted textile finishing without causing undesirable effects.

In the current study, protease was investigated to selectively modify a wool/polyester blended fabric to impart decorative surface effects. A series of control experiments were conducted, consisting of different processing parameters being investigated on a wool/polyester blend using protease within a long liquor solution to study the interaction between enzyme and substrate. Experiments concentrated on achieving either partial or complete removal of the dyed wool fibres with a view to revealing undyed polyester yarns which formed part of the fabric blend. Furthermore, enzymatically treated samples would be tested against commercial standards to determine tensile strength properties. Knowledge gained from control experiments would be exploited for aesthetic design purposes in the design phase of this study.

\section{Materials and methods}

\subsection{Materials}

A plain woven wool/polyester (45/55\%) blended fabric, with a dry weight of $163 \mathrm{~g} / \mathrm{m}^{2}$ was supplied by Inotex (Czech Republic). The enzyme used was a commercial alkaline protease Esperase $8.0 \mathrm{~L}$ (Novozymes) with the corresponding Enzyme Commission number EC 3.4.21.62 purchased from Sigma-Aldrich. Ultravon PL (UPL), a synergetic preparation based on non-ionic surfactants (Huntsman Textile Specialities) was purchased from Town End (Leeds, UK). The reactive dye Lanasol Blue CE 
and the levelling auxiliary Albegal B were supplied by Huntsman Textile Specialities (UK). All other chemicals used were of specified laboratory reagent grade.

\subsection{Pre-treatment of wool/polyester fabric by alkaline scour}

To enhance subsequent enzyme treatment, fabric samples were pre-washed in a two-step alkaline scouring process. In the first step, the samples were washed in a solution containing $1.6 \mathrm{~g} / \mathrm{L}$ of sodium carbonate and $2 \mathrm{~g} / \mathrm{L}$ of UPL at $60^{\circ} \mathrm{C}$ for 30 minutes, at a liquor to goods ratio of $50: 1$ at an agitation speed of $5 \mathrm{rpm}$, followed by a tap water rinse. The second step was a deionised water rinse at $60^{\circ} \mathrm{C}$ for 10 minutes, at a liquor to goods ratio of 50:1 at an agitation speed of $5 \mathrm{rpm}$, followed by a water rinse. Samples were then left to air-dry at room temperature.

\subsection{Dyeing method}

Wool/polyester fabric samples were dyed before enzyme treatment using a reactive dye, Lanasol Blue $\mathrm{CE}$. The fabric was treated for 30 minutes at $50^{\circ} \mathrm{C}$ in a dye bath containing $2 \%$ omf (on mass of fibre) acetic acid, 5\% omf sodium sulphate and $1 \%$ omf Albegal B, a levelling agent. Then $2 \%$ or $5 \%$ omf Lanasol Blue $\mathrm{CE}$ was added to the dye bath and the temperature was raised to $100^{\circ} \mathrm{C}$ at the rate of $1.5^{\circ} \mathrm{C} / \mathrm{min}$ and maintained at $100^{\circ} \mathrm{C}$ for 90 minutes. After dyeing, the fabric was treated in a $1 \% \mathrm{omf}$ ammonia solution at $80^{\circ} \mathrm{C}$ for 15 minutes. Dyeing took place in a Datacolor Ahiba Nuance IR dye machine at an agitation speed of $5 \mathrm{rpm}$ with a liquor to goods ratio of 30:1. Samples were rinsed with water after dyeing was complete and left to air-dry at room temperature.

\subsection{Enzyme treatment}

Dyed wool/polyester fabric samples $(2 \mathrm{~g}$ ) were treated with either 100 or $200 \mu \mathrm{L}$ of Esperase in $0.02 \mathrm{M}$ tetraborate buffer containing $0.05 \mathrm{M}$ of sodium sulphite and set at $\mathrm{pH} 8.5$ with a liquor to goods ratio of $50: 1$ for $0.5,1,2$, or 4 hours at $50^{\circ} \mathrm{C}$ or $60^{\circ} \mathrm{C}$. Treatment took place in a Datacolor Ahiba Nuance IR dye machine set to an agitation speed of 5 or $40 \mathrm{rpm}$. A control sample containing no enzyme was also run for comparison. After the enzyme treatment, the temperature was raised to $80^{\circ} \mathrm{C}$ and maintained for 10 minutes to denature the enzyme. Enzyme treated samples were then washed in a solution containing $2 \mathrm{~g} / \mathrm{L}$ of UPL at $60^{\circ} \mathrm{C}$ for 10 minutes, at a liquor to goods ratio of $50: 1$. Treatments took place in a Datacolor Ahiba Nuance IR dye machine set to an agitation speed of $20 \mathrm{rpm}$, followed by a water rinse and left to air-dry at room temperature.

\subsection{Determination of weight loss due to enzyme treatment}

The weight of fabric samples was measured prior to and after enzyme treatment. The total weight loss of the fabric samples after enzyme treatment was determined and expressed as a percentage calculated using Equation (1):

Weight loss $(\%)=100 \times\left(\mathrm{W}_{1}-\mathrm{W}_{2}\right) / \mathrm{W}_{1}$ 
where $\mathrm{W}_{1}$ is the weight of the wool/polyester fabric prior to enzyme treatment and $\mathrm{W}_{2}$ is the weight of the fabric after enzyme treatment.

\subsection{Scanning electron microscopy (SEM) analysis of enzyme treated fabric samples}

To determine changes to the surface of the fabric after enzyme treatment and examine the extent of fibre damage, micrographs were taken using SEM. The fabric samples were prepared by attaching a double-sided adhesive carbon tab to an aluminium stub, a small cutting of the fabric sample was then placed on to the sticky surface of the stub. Fabric samples were then sputter coated with gold under argon for 60 seconds using a Quorum Q150RS rotary-pumped sputter coater. Fabric samples were examined using a Carl Zeiss EVO HD 15 scanning electron microscope operating with a working distance of 9 or $9.5 \mathrm{~mm}$ with an accelerating voltage of 5 or $10 \mathrm{kV}$, and a magnification of $250 \mathrm{x}$ or 2500x.

\subsection{Colour measurement}

A Datacolor SF600 Plus CT reflectance spectrophotometer with an aperture diameter of $6.6 \mathrm{~mm}$ was used to determine the colour strength and differences of enzyme treated wool/polyester fabric samples, represented by the CIE $L^{*} a^{*} b^{*}$ colour space system. $K / S$ values were also recorded, which are directly proportional to the concentration of colorant in the fabric. Each fabric sample was folded into four and measured four times. All values were measured and calculated under controlled conditions using ColorTools QC software with the illuminant and observer conditions of $\mathrm{D}_{65}$ and $10^{\circ}$, respectively. An average colour measurement was calculated from the data collected for each fabric sample.

Colour strength values were calculated using the Kubelka-Munk equation, Equation (2):

$K / S=(1-R)^{2} / 2 R$

where $\mathrm{R}$ is the reflectance at the surface of the substrate illuminated with light of a known wavelength, $\mathrm{K}$ is the absorption coefficient and $\mathrm{S}$ is the scattering coefficient.

Colour differences between control samples and enzyme-treated samples are represented as $\Delta E$ and were calculated using Equation (3):

$\Delta E=\left[(\Delta L *)_{2}+(\Delta a *)_{2}+(\Delta b *)_{2}\right]^{1 / 2}$

where $\Delta L^{*}, \Delta a^{*}$, and $\Delta b^{*}$ represent the differences between the corresponding units of each sample. 
In addition, liquor analysis of enzyme treatment solutions were conducted before and after the enzyme process to determine loss of colour from the fabric samples during enzyme treatment. Solutions were made up to the same fixed volume and absorbance measurements were taken at $600 \mathrm{~nm}$ (the wavelength of maximum absorption $\left(\lambda_{\max }\right)$ specific to the reactive dye Lanasol Blue CE) using a Unicam SP1800 $\mathrm{UV} /$ visible spectrophotometer.

\subsection{Tensile strength properties of enzyme treated fabric samples}

To determine changes in mechanical properties of enzyme treated wool/polyester woven fabrics, tensile strength tests were performed using an Instron 3345 with Bluehill 3 software. The test method BS EN ISO 13934-1:2013 Part 1: Determination of maximum force and elongation at maximum force using the strip method was used. Two sets of samples, one set in the warp direction and the other in the weft direction were prepared. Each set consisting of 5 samples cut to the length of $300 \mathrm{~mm}$ and width of 60 $\mathrm{mm} \pm 0.5 \mathrm{~mm}$. Each sample was extended at a constant rate of extension of $100 \mathrm{~mm} / \mathrm{min}$ until it ruptured, using a gauge length of $200 \mathrm{~mm}$ and load cell of $2 \mathrm{~N}$. The mean of load at break (N) and tensile strain (extension) at break (\%) was recorded.

\subsection{Design sample preparation}

Wool/polyester fabric samples ( $9 \mathrm{~g}$ ) were alkaline scoured and then dyed with $2 \%$ omf Lanasol Blue CE reactive dye, using the methods described in Sections 2.2 and 2.3. Dyed fabrics were either stitched, folded or pleated, and secured in place by clamps with wooden blocks, or stitched in place using thread and then enzyme treated and washed as described in Section 2.4.

\subsubsection{Stitch resist patterning}

Sample A was prepared by hand stitching a single layer of wool/polyester fabric with a doubled thread equally spaced running stitch. Multiple parallel single lines were stitched through flowing folded stripes diagonally across the fabric, resembling the illustrated diagram in Fig. 1. Similarly, Sample B was prepared using a single layer of fabric, handstitched using a doubled thread running stitch with even spacing and stitch length in a constant forward movement (Fig. 2). Multiple parallel rows were stitched. After stitching was complete the fabrics were drawn into tight gathers along the stitched threads and secured by knotting, creating discontinuous irregular folds along the fabric.

\subsubsection{Folded, pleated and clamped resist patterning}

Samples C and D were prepared by folding wool/polyester fabrics into precise vertical pleats. The pleated fabric strip was then repeatedly reverse folded, either horizontally or diagonally into a square or triangular form, largely dictated by the design desired. The folded fabric was then clamped into place between wooden blocks using strong pressure applied by a metal G-clamp, as illustrated in Fig. 3 and 4. 


\section{Results and discussion}

3.1. Effect of sodium sulphite on the enzyme treatment of dyed wool/polyester blended fabrics A plain woven wool/polyester (45/55\%) blended fabric was selected for this study, as it comprised of two distinct fibre types. The wool component of the fabric is an ideal substrate for a protease such as Esperase, which is capable of breaking down proteins by hydrolysing peptide bonds in the wool fibre, but due to substrate specificity has no effect towards the polyester fibre.

Previous studies (Bishop et al., 1998; Shen et al., 1999) have reported that the action of protease on undamaged wool is slow because of the protective hydrophobic epicuticle surface layer and the highly crosslinked cuticle cell components beneath. Once some of the disulphide crosslinks in the amino acid residues forming the cuticle cells are broken, the rate of enzyme reaction is greatly increased. Previous studies have shown a pre-treatment with sodium sulphite to be useful for promoting proteolytic hydrolysis (Shen et al., 1999). To determine whether it was necessary to add the reducing agent sodium sulphite to accelerate wool hydrolysis, wool/polyester fabric samples dyed with 5\% omf Lanasol Blue $\mathrm{CE}$ were treated in a solution containing Esperase with or without the addition of sodium sulphite.

Fabric samples treated with only Esperase resulted in the maximum weight loss of $2 \%$ with no visible colour change after a 4 hour treatment as shown in Table 1 . In contrast, the same treatment conditions with the addition of sodium sulphite resulted in a much greater weight loss of $20 \%$ with a visible colour difference $(\Delta E)$ of 13.4. Longer treatment times resulted in greater weight loss and lighter shades being produced, as reflected by $K / S$ and $\Delta E$ values. Liquor analysis of enzyme treatment solutions were also conducted. Liquors collected from treatments containing Esperase with the addition of sodium sulphite were notably darker in colour due to the presence of dyed wool residue as shown in Fig. 5. Results in Fig. 5 also indicated longer treatment times led to greater loss of colour from fabric samples, with liquor absorbance values (at $600 \mathrm{~nm}$ ) increasing from 0.5 to 1.5 for treatments with Esperase only, and from 1.9 to 3.8 for treatments containing Esperase with the addition of sodium sulphite.

Micrographs were taken using SEM of untreated and treated fabric samples. The untreated wool/polyester sample (Fig. 6) showed the presence of wool fibres, which are identified by a rough texture composed of overlapping scales, and polyester fibres which are identified by a smooth round surface. The wool/polyester sample treated with protease for 4 hours in the presence of sodium sulphite (Fig. 7) revealed severe wool fibre damage at higher magnification. Fig. 7 shows broken and shredded wool fibres spotted in between unaffected polyester fibres. These results confirm protease is capable of effectively breaking down wool fibres once the cuticle cell has been disrupted, as it permits enzyme diffusion into the inner part of the wool fibre leading to complete degradation (Shen, 2010). No 
modifications or damage to the surface of the polyester fibre were observed, confirming the ineffectiveness of Esperase towards polyester.

Results confirmed the addition of sodium sulphite promoted proteolytic hydrolysis when disulphide crosslinks of cystine dimers are broken enabling enzymes to diffuse and disrupt the cell membrane causing damage to the wool fibre, resulting in greater weight loss and fading of fabric, but leaving the polyester component intact. Consequently, in the present work sodium sulphite was considered necessary to effectively degrade wool fibres from the fabric blend as it shortened the reaction times.

\subsection{Effect of enzyme concentration on the treatment of dyed wool/polyester blended fabrics}

Results obtained from the initial experiment confirmed it was possible to remove dyed wool fibres from the selected blend to reveal the undyed polyester component of the plain weave; a maximum weight loss of $20 \%$ over a 4 hour treatment was observed. It was hoped a weight loss close to or greater than $40 \%$ from the $45 / 55 \%$ (wool/polyester) blend would give rise to greater colour contrast and design pattern options. It was considered whether treating wool/polyester samples dyed with $2 \%$ or $5 \%$ omf Lanasol Blue CE using the same conditions, but with higher concentrations of Esperase would be effective in achieving a higher level of weight loss with the possibility of reduced treatment times.

The results in Table 2 confirm an increased concentration of Esperase in the liquor solution was more effective in removing wool fibres from the fabric blend. Samples dyed with 5\% omf resulted in a weight loss increase ranging from 8.5 to $29 \%$, confirming an increase in the concentration of enzyme resulted in an increased weight loss of $9 \%$ after a 4 hour treatment, compared to previous results (Table 1). A higher weight loss was recorded at all measured intervals for samples dyed with $2 \%$ omf, weight loss ranging from 10 to $40.5 \%$. These results suggest Esperase was more effective towards the wool fibre at a lower concentration of dye. Therefore, larger quantities of dye on the surface of the wool fibre may prevent the enzyme binding with the substrate. The reactive group on Lanasol dyes is a $\alpha$ bromoacrylamide, which acts as a bifunctional reactive group if sufficient nucleophiles are available to react with or if steric hindrance does not take place (Lewis, 1992). Therefore, due to the essential bifunctionality of its reactive group, the Lanasol Blue CE dye used could crosslink the polypeptides in the wool fibres, therefore restricting proteolytic hydrolysis towards dyed wool.

\subsection{Effects of increased temperature during enzyme treatment}

Temperature plays an important role in governing the catalytic activity of an enzyme. Enzyme activity increases with temperature up to an optimum temperature beyond which activity decreases sharply as the enzyme structure is disrupted with extreme temperatures leading to denaturation. Different proteases have characteristic temperatures at which their catalytic activity is highest. The optimum processing temperature for Esperase ranges between $50^{\circ} \mathrm{C}$ and $65^{\circ} \mathrm{C}$ (Zhang et al., 2006). Additional experiments were carried out to determine whether an increase in temperature would promote greater weight loss 
and colour contrast. Fabric samples dyed with $2 \%$ omf Lanasol Blue CE were enzymetreated using temperatures of $50^{\circ} \mathrm{C}$ and $60^{\circ} \mathrm{C}$. Enzyme treatments were followed up with a gentle rinsing step to remove loose fibres from the fabric structure. As with earlier experiments it was noted that greater water agitation during the rinse off led to more loose fibres being removed from the fabric. It was therefore considered necessary to introduce a soap wash post enzyme treatment to aid the removal of loose fibres still attached to the fabric construction.

Enzyme activity towards the substrate was enhanced with an increase in temperature as seen in Table 3. A greater degree of wool hydrolysis from the fabric was recorded with the sample treated at $60^{\circ} \mathrm{C}$, with weight loss of $36.5 \%$ after a 4 hour treatment, therefore removing approximately $81 \%$ of the wool fibre component present, in comparison with the sample treated at $50^{\circ} \mathrm{C}$ which resulted in $27.5 \%$ weight loss. A prolonged 8 hour treatment at $50^{\circ} \mathrm{C}$ eventually yielded a similar weight loss to the sample treated for 4 hour at $60^{\circ} \mathrm{C}, 35 \%$ and $36.5 \%$ respectively. Enzyme reaction rates were greatly increased with the use of $60^{\circ} \mathrm{C}$, leading to a high fabric weight loss, therefore offering opportunities for reducing processing times. Results suggest similar effects could be achieved by processing at the lower temperature of $50^{\circ} \mathrm{C}$ with extended reaction times. Samples treated for 30 minutes to 1 hour at $60^{\circ} \mathrm{C}$ showed greatly enhanced enzyme activity, this was reflected in the accelerated weight loss recorded, which increased by approximately twofold when compared to treatments carried out at $50^{\circ} \mathrm{C}$. Wool fibre hydrolysis of the fabric remained relatively constant beyond a 4 hour treatment using $50^{\circ} \mathrm{C}$, and 2 hour treatment using $60^{\circ} \mathrm{C}$, with weight losses not continually increasing with prolonged processing times. These results suggest an increase in weight loss or total removal of the wool component from the $45 \%$ wool $/ 55 \%$ polyester blend may not be achievable with prolonging treatment times. If complete wool fibre hydrolysis was achieved a $45 \%$ weight loss would be expected.

Wool/polyester fabric samples treated with Esperase at $60^{\circ} \mathrm{C}$ were examined using SEM (Fig. 9) and compared to a control sample treated in the absence of Esperase (Fig. 8). Clear differences were observed between samples. As the duration of enzyme treatment increased, a visible reduction of wool fibres within the fabric construction was observed. A sharp decrease in wool fibres was observed at the first measured interval of 30 minutes. This suggested the enzyme treatment was very effective in the first 30 minutes, with considerable visible wool fibre damage amongst polyester fibres (image not shown). By increasing treatment times, greater loss of wool fibres resulted in the transformation of the plain weave fabric structure into a more open and loose weave structure. At higher magnification, shredded cut-off and damaged wool fibre fragments can be seen trapped amongst exposed polyester fibre bundles of the yarn, especially at points where the warp and weft yarns meet (Fig. 9). No polyester damage was noted. In contrast, the control sample displayed a more compact plain weave with closely and neatly packed together fibres without visible damage to either the wool or polyester fibres. A greater percentage of wool fibres are visible amongst the fabric construction, identifiable by distinctive scales on the surface (Fig. 8). 
The SEM images indicate yarn and fabric structure may govern maximum wool hydrolysis achievable from fabric blends. Esperase can effectively breakdown wool fibres into fragments. These fragments may remain trapped amongst other fibres unable to free themselves from the yarn structure. This may lead to limited wool being removed from the main structure resulting in incomplete colour fading due to the complete hydrolysis of wool being unachievable. SEM images also suggest Esperase may have limited access to fibres within the interior of the yarn (tightly packed fibres) and areas where the warp and weft meet. Suggesting fibres on the surface may only be accessible. Fabrics with looser constructions may lead to more exposed fibre surface areas which would be more easily degraded, for example knitted fabrics may lead to higher yields of weight loss than woven structures.

A reactive dye was selected for this study because of its superior wash fastness properties. Liquor analysis was performed after enzyme treatment. The reactive Lanasol Blue CE dye showed very good fastness to wet treatments, because a very small amount of dye was detected in the liquor containing the control sample. However, enzyme treatments with Esperase resulted in highly coloured liquors, with absorbance measurements increasing with longer processing times and elevated temperatures as seen in Fig. 10. The highest absorbance value (at $600 \mathrm{~nm}$ ) of 3.4 was recorded for the sample treated with $60^{\circ} \mathrm{C}$ for 4 hours. This sample also recorded the greatest weight loss. Results confirmed that the covalently bound dye was not responsible for the fading effect observed on the fabric samples, but a direct result of coloured wool fibres being removed from the main construction of the fabric revealing the undyed polyester yarns. This confirms that the observed weight loss and fading of the samples were achieved by enzyme hydrolysis of peptide bonds in the wool fibre.

\subsection{Effects of increased agitation during enzyme treatment}

Previous studies (Cavaco-Paulo, 1998; Cortez et al., 2001; Vasconcelos et al., 2006) have reported greater mechanical agitation during enzyme treatment with cellulases can lead to enhanced enzyme activity towards its substrate. This suggests that increased agitation during enzyme treatment could promote greater wool hydrolysis leading to enhanced colour differences being achieved. To explore the possibilities, a further experiment was conducted using the temperature of $60^{\circ} \mathrm{C}$ with the increased agitation speed of $40 \mathrm{rpm}$.

Similar to previous experiments, the results in Table 4 show that as treatment times progressed a greater weight loss was recorded. A higher level of agitation resulted in a very slight increase in weight loss after a 4 hour treatment. Therefore, approximately $86.5 \%$ of the wool fibre component from the blend could be removed. A distinctive visual effect was also observed. A decrease in uniformity across the samples was noticed, with considerable amounts of coloured wool fibres removed from areas to reveal patches of undyed polyester yarns, especially where folds or creases incurred during enzyme treatment. This effect was most visible with the sample treated for 4 hours (Table 4). Results suggest greater agitation was responsible for promoting enzyme accessibility through inter-fibre, inter-yarn friction and 
liquor beating action. As treatment times increased, wool hydrolysis and liberation of trapped insoluble wool fragments through greater agitation resulted in the fabric structure opening up with greater accessibility to enzymes in areas especially where folds and creases formed. Although complete wool hydrolysis was not achieved, a relationship between weight loss and colour fading emerged. Greater weight loss resulted in lighter coloured shades and lighter weight fabrics being produced.

\subsection{Tensile strength of enzyme-treated wool/polyester fabrics}

The effects of enzyme treatment on the mechanical properties of the wool/polyester woven fabrics were investigated. Tensile strength tests using the strip method were performed to determine changes in tensile strength and elongation. The results for the load at break $(\mathrm{N})$ and tensile strain (extension) at break (\%) can be found in Table 5 .

The most promising conditions which resulted in the greatest weight loss after enzyme treatment from this study were selected for testing. Wool/polyester fabric samples dyed with $2 \%$ omf Lanasol Blue CE were enzyme treated in a solution containing Esperase with the addition of $0.05 \mathrm{M}$ sodium sulphite at $60^{\circ} \mathrm{C}$ for 4 hours with the agitation speed of $40 \mathrm{rpm}$.

Enzyme treatment resulted in a decrease in tensile strength and elongation in both warp and weft directions. The fabric weft had a greater loss in strength than that of the warp, with a strength loss of $39.9 \%$ and $28.8 \%$ load at break, respectively. Results indicate enzyme treatment was the cause of reduced tensile strength, suggesting wool fibre hydrolysis from the main structure of the fabric caused weakening of the fabric. Even though the tensile strength of the treated fabrics was lower than the untreated samples, the values recorded appear to be within the accepted guidelines of Woolmark specification AW-1: 2016 and IF-1: 2016, indicating enzyme treated fabrics comply with all Woolmark apparel product standard and meet mandatory requirements for furnishing fabrics in both the warp and weft directions as outlined in specifications [The Woolmark Company 2016].

\subsection{Generation of surface design patterns}

From the knowledge gained during control studies, the decorative pattern design potential of protease was explored to see if effects similar to conventional surface design processes such as devoré or discharge printing could be achieved. Patterns consisting of simple repeats of design elements (Wells, 2000) such as, lines or geometric shapes were chosen for exploration to create an all-over repeat pattern across the length of fabric. A combination of different surface patterning design techniques inspired from traditional Shibori resist dyeing methods (Wada, 2012) were selected for design trials. A range of dyed wool/polyester fabric samples comprising of different degrees of compression and accessibility were prepared using stitching, or folding, pleating and clamping (as illustrated in Figs 1 - 4) to investigate the quality of mark that could be achieved through enzyme processing. 
Results successfully demonstrated, surface patterning could be achieved with enzyme processing wool/polyester fabric samples prepared using resist techniques. The use of stitch resist techniques (Figs. 1 and 2) resulted in free-flowing linear textural patterning constructed from soft delicate lines after enzyme processing, see Fig. 11 and 12. Sample A was created with the use of loose handstitching; a unique diagonal stripe effect with a subtle textured background was generated after enzyme processing. The design technique allowed liquor containing enzymes accessibility to most of the fabric during enzyme processing, as a result a substantial amount of coloured wool fibres were removed from the fabric construction, leading to a greater proportion of the white undyed polyester yarns to be revealed. This resulted in a lighter coloured and weight fabric. Despite large amounts of wool fibre being removed from the fabric structure during processing, the fabric structure remained intact. A different hand stitched technique was used to create Sample B (Fig. 12), which resulted in simple free-flowing broken vertical stripe patterning across the length of the fabric. Tighter gathering of the fabric before processing resulted in slowing down liquor accessibility, therefore Sample B was able to retain a larger component of its coloured wool fibres in comparison to Sample A.

In contrast, the use of pleat, fold and clamp resist design techniques (Figs. 3 and 4) for samples $\mathrm{C}$ and D generated bold structured geometric patterns. Multiple pleats and folds enabled the creation of lattice interlaced patterning composed of coloured graduation effects by enzyme processing. Samples $\mathrm{C}$ and D were generated using similar pleat and fold resist techniques with the use of a G-clamp to restrict enzyme access to areas of the fabric during enzyme treatment. The resist technique used for sample $\mathrm{C}$ generated a soft-edged triangle repeat pattern across the fabric (Fig. 13), in contrast the use of a slightly different pleat and fold technique resulted in a soft-edged square repeat pattern to be generated on sample D (Fig. 14). Both patterns reflected the shapes (triangle/square) into which the fabric was folded and clamped before enzyme processing. The use of a G-clamp resulted in the formation of patterns with stronger areas of colour contrast, observed on both designs. Greater enzyme liquor accessibility to the outermost sharp fabric folds resulted in areas of greater resist, these became blurry with reduced fading as the folds sitting within other folds increased. The innermost central parts of the fabric remained inaccessible to the liquor, therefore no fading took place.

Results successfully demonstrated a diverse range of highly individual patterns could be generated with the use of different stitch, or pleat, fold and clamped resist techniques trialled with enzyme processing. Each technique used, heavily governed the degree of liquor accessibility and penetration, and consequently the level of wool degradation and the resulting visual aesthetic qualities. Stitch techniques employed, enabled greater access to the enzyme containing liquor, resulting in softer coloured visual effects. In contrast, pleat, fold and clamp techniques allowed a different style of patterning to be generated with enzyme processing. Designs with greater colour contrasts and stronger depths of shade resulted due to the increased level of pressure and compression applied with the Gclamp, restricting enzyme access to areas of the fabric. 
The characteristics of the patterned designs produced were heavily governed by the process; irregular surface modification resulted in subtle pattern variations and irregularities, and design elements displayed distinctive soft-edges. The enzymatic process lends itself to applications where nonidentical, but corresponding designs may be desired.The outcomes suggest many other possibilities, exploring other types and arrangements of stitch directions and lengths, or the development of complex pleats and folds into the fabric could be explored. Effects produced using this type of resist technique are quite different from sharp-edged resist designs obtained with either wax resists or stencils, these could be explored to achieve various other qualities of marks and lines.

\section{Conclusions}

Enzyme treatments proved to be an effective method for hydrolysing dyed wool fibres from the main wool/polyester blended fabric structure without affecting the polyester component. The use of optimum reducing agent, enzyme concentration and processing parameters during enzyme treatment proved beneficial for promoting greater dyed wool hydrolysis and liberation of wool fibre fragments from the main structure of the fabric, resulting in lighter weight fabrics with a soft handle and visible fading. Results suggested lower concentrations of Lanasol Blue CE dye (\% omf) on the wool fibre promoted enzyme activity towards wool fibres. Complete wool hydrolysis from the fabric blend was not achieved, however, the removal of up to $85.6 \%$ of wool present in a $45 \%$ wool $/ 55 \%$ polyester blend was achieved. Microscopic images revealed trapped wool fibre fragments amongst polyester fibres, suggesting that different fabric weave structures may influence the level of wool hydrolysis possible. Although a large quantity of the wool fibre was removed, the fabric structure retained adequate physical strength and structural stability, with tensile strengths still meeting industry wool standards.

This study demonstrates the ability of protease as a novel creative tool for effective surface patterning through controlled degradation. Selected areas of the fabric made accessible to the enzyme containing liquor using different fabric resist techniques enabled decorative surface patterning to be achieved on the wool/polyester blend. Treatment with protease resulted in areas of defined colour contrast, as sufficient hydrolysis of dyed wool fibres revealed areas of undyed polyester fibres. The technique developed shares visual qualities similar to that of devoré and discharge printing.

Surface patterning with protease presents clear advantages above conventional surface patterning processes. Principally the novel process significantly reduces the use of reducing agents, and eliminates the use of chemical auxiliaries traditionally used in conventional processes, offering simpler, cleaner and safer alternative processing methods. Currently there is interest within the textile industry to create fabrics with artisan aesthetics. The process developed offers new unique design aesthetics, which enables the production of individual surface design patterns with subtle variations, irregularities, and unique characteristics which would be difficult to reproduce and replicate by the means of conventional 
textile processes. These qualities are understood and valued to be positive in the current industry where consumers regularly seek individual and unique pieces. The opportunities discussed in this paper could provide the textile industry with realistic and viable options to use enzyme-based surface patterning processes with the potential to move forward towards sustainable development.

\section{Acknowledgements}

The authors would like to thank the Arts and Humanities Research Council (AHRC) for funding the collaborative LEBIOTEX Project (AH/J002666/1) between De Montfort University and Loughborough University.

\section{References}

Araújo, R., Casal, M., Cavaco-Paulo, A., 2008. Application of enzymes for textile fibres processing. Biocatal. Biotransfor. 26, $332-349$.

Araújo, R., Silva, C., Machado, R., Casal, M., Cunha, A. M., Rodriguez-Cabello, J. C., Cavaco-Paulo, A., 2009. Proteolytic enzymes engineering: A tool for wool. Biomacromolecules. 10, $1655-1661$.

Bishop, D. P., Shen, J., Heine, E., Hollfelder, B., 1998. The use of proteolytic enzymes to reduce wool fibre stiffness and prickle. J. Text. Inst. 89, $546-553$.

Cavaco-Paulo, A., 1998. Mechanism of cellulase action in textile processes. Carbohydr. Polym. 37, 273 277.

Clarke, S., 2011. Textile Design. Laurence King, London.

Cortez, J. M., Ellis, J., Bishop, D. P., 2001. Cellulase finishing of woven, cotton fabrics in jet and winch machines. J. Biotechnol. 89, 239 - 245.

Fulton, C. W., 1908. Production of patterns, designs, or other similar markings. US Patent 880,983.

Kinnersly-Taylor, J., 2003. Dyeing and screen-printing on textiles. A \& C Black Publishers, London.

Lacasse, K. and Baumann, W., 2012. Textile Chemicals: Environmental Data and Facts. SpringerVerlag Berlin Heidelberg, Germany.

Lewis, D. M., 1992. Dyeing wool with reactive dyes. In: Lewis, D.M. (Ed.), Wool Dyeing. Society of Dyers and Colourists, Bradford, 222-256. 
Maertens, E., 1886. Art of making textile fabrics. US Patent 341,927.

Makarov, S. V., Mundoma, C., Svarovsky, S. A., Shi, X., Gannet P. M., Simoyi R. H., 1999. Reactive oxygen species in the aerobic decomposition of sodium hydroxymethanesulfinate. Arch. Biochem.

Biophys. 367, 289-296.

Miles, L. W. C., 1994. Textile Printing. Society of Dyers and Colourists, Bradford.

Nielsen, P. H., Kuilderd, H., Zhou, W., Lu, X., 2009. Enzyme biotechnology for sustainable textiles. In: Blackburn, R.S. (Ed.), Sustainable Textiles, Life Cycle and Environmental Impact. Woodhead Publishing, Cambridge, 113 - 138.

Nolte, H., Bishop, D. P., Höcker, H., 1996. Effects of proteolytic and lipolytic enzymes on untreated and shrink-resist-treated wool. J. Text. Inst. 87, $212-226$.

Payne, J., 2010. Cutting Through the Surface: The Use of Laser Cutting Technology with Traditional Textile Process. Textile Society of America Symposium Proceedings. 43. http://digitalcommons.unl.edu/tsaconf/43

Prajapati, C. D., 2016. Biotechnology for Textile Coloration and Surface Pattern. PhD, De Montfort University, UK.

Robertson, A., 2006. Tracing the Temporary Thread: Decorative and Functional Devoré Textiles of the Early Twentieth Century. Textile Society of America Symposium Proceedings. 329.

http://digitalcommons.unl.edu/tsaconf/329

Shen, J., Bishop, D. P., Heine, E., Hollfelder, B., 1999. Some factors affecting the control of proteolytic enzyme reaction on wool. J. Text. Inst. 90, $404-411$.

Shen, J., Rushforth, M., Cavaco-Paulo, A., Guebitz, G., Lenting, H., 2007. Development and industrialisation of enzymatic shrink-resistant process based on modified proteases for wool machine washability. Enzyme Microb. Technol. 40, 1656 - 1661.

Shen, J., 2010. Enzymatic treatment of wool and silk fibres. In: Nierstrasz, V. A. and Cavaco-Paulo, A. (Eds.), Advances in textile biotechnology. Woodhead Publishing, Cambridge, 171 - 192. 
Shen, J. and Smith, E., 2015. Enzymatic treatments for sustainable textile processing. In: Blackburn, R. (Ed.), Sustainable Apparel, Production, Processing and Recycling. Woodhead Publishing, Cambridge, $119-133$.

Silva, C. J. S. M., Zhang, Q., Shen, J., Cavaco-Paulo, A., 2006. Immobilization of proteases with a water soluble-insoluble reversible polymer for treatment of wool. Enzyme Microb. Tech. 39, 634-640.

Smith, E., Zhang, Q., Shen, J., Schroeder, M., Silva, C., 2008. Modification of Esperase ${ }^{\circledR}$ by covalent bonding to Eudragit ${ }^{\circledR}$ polymers L 100 and S 100 for wool fibre surface treatment. Biocatal.

Biotransfor. 26, $391-398$.

Smith, E., Schroeder, M., Guebitz, G., Shen, J., 2010. Covalent bonding of protease to different sized enteric polymers and their potential use in wool processing. Enzyme Microb. Tech. 47, $105-111$.

Smith, E. and Shen, J., 2011. Surface modification of wool with protease extracted polypeptides. J. Biotechnol. 156, $134-140$.

Smith, E. and Shen, J., 2012. Enzymatic treatment of wool pre-treated with cetyltrimethylammonium bromide to achieve machine washability. Biocatal. Biotransfor. 30, $38-47$.

Stoyel, J., 2007. Laser and Devoré. In: Miraftab, M. and Horrocks, A. R. (Eds.), Ecotextiles: The way forward for sustainable development in textiles. Woodhead Publishing, Cambridge, $210-215$.

The Woolmark Company, 2016. Woolmark Specification, Flat woven, pile woven and pressed felt apparel products, Specification AW-1. The Woolmark Company, Australia.

The Woolmark Company, 2016. Woolmark Specification, Furnishing fabrics, Specification 1F-1. The Woolmark Company, Australia.

Timme, O., 1902. Method of producing figured pile fabrics. US Patent 705,977.

Vasconcelos, A., and Cavaco-Paulo, A., 2006 Enzymatic removal of cellulose from cotton/polyester fabric blends. Cellulose. 13, $611-618$.

Vílchez, S., Jovancic, P., Manich, A. M., Julià, M. R., Erra, P., 2005. Chitosan application on wool before enzymatic treatment. J. Appl. Polym. Sci. 98, 1938 - 1946. 
Vílchez, S., Manich, A. M., Jovancic, P., Erra, P., 2008. Chitosan contribution on wool treatments with enzyme. Carbohydr. Polym. 71, 515 - 523.

Wada, Y., Rice, M., Barton, J., 2012. Shibori: The Inventive Art of Japanese Shaped Resist Dyeing. Kodansha International, Tokyo, Japan.

Watkins, P., 2017. Survey of the European fabric fairs for spring/summer 2018. Textile Outlook International. $186,29-56$.

Wells, K., 2000. Fabric Dyeing \& Printing. Conran Octopus Limited, London.

Zhang, Q., Smith, E., Shen, J., Bishop, D., 2006. An ethoxylated alkyl phosphate (anionic surfactant) for the promotion of activities of proteases and its potential use in the enzymatic processing of wool. Biotechnol. Lett. 28, $717-723$. 
1

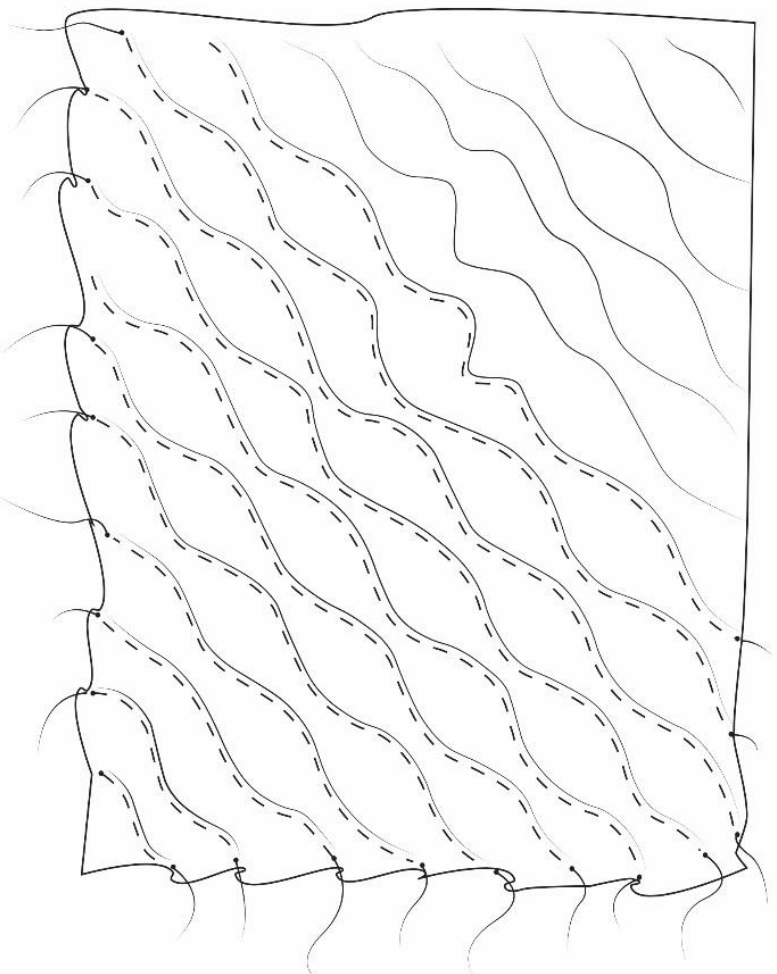

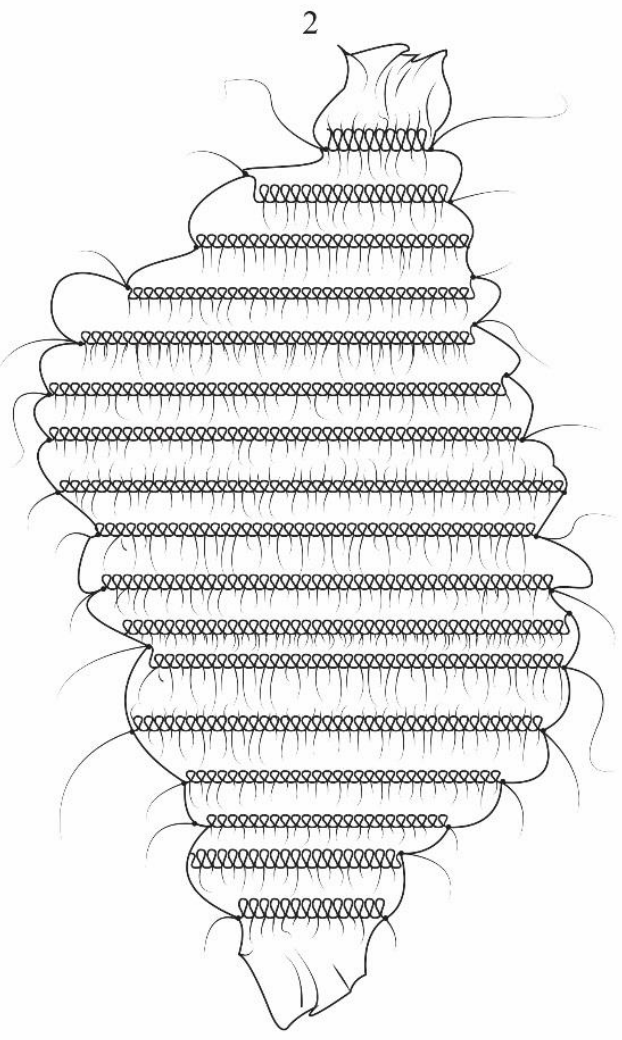

Fig. 1. Illustrated diagram showing handstitched Shibori technique used to create sample A. 

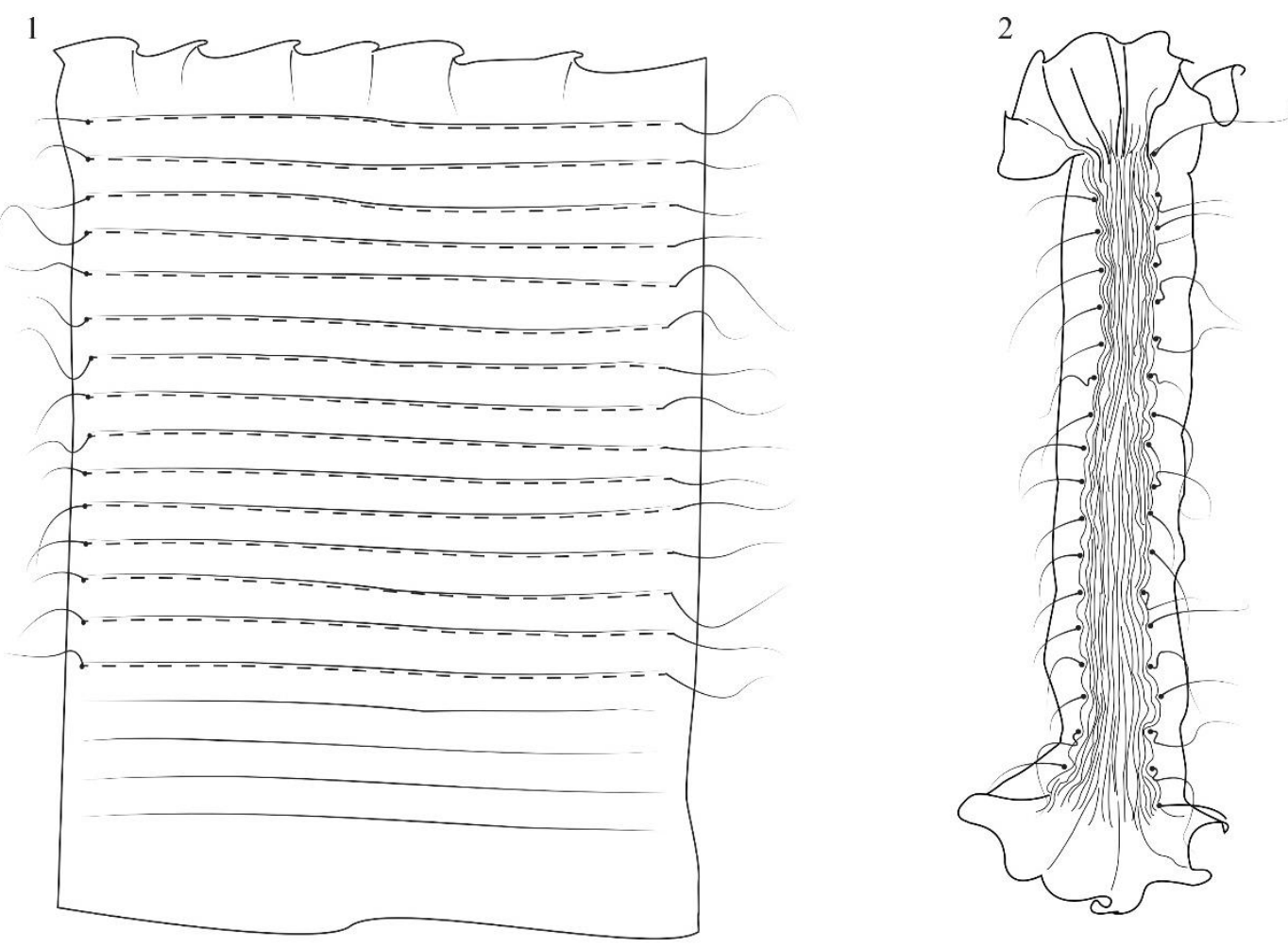

Fig. 2. Illustrated diagram showing handstitched Shibori technique used to create sample B. 


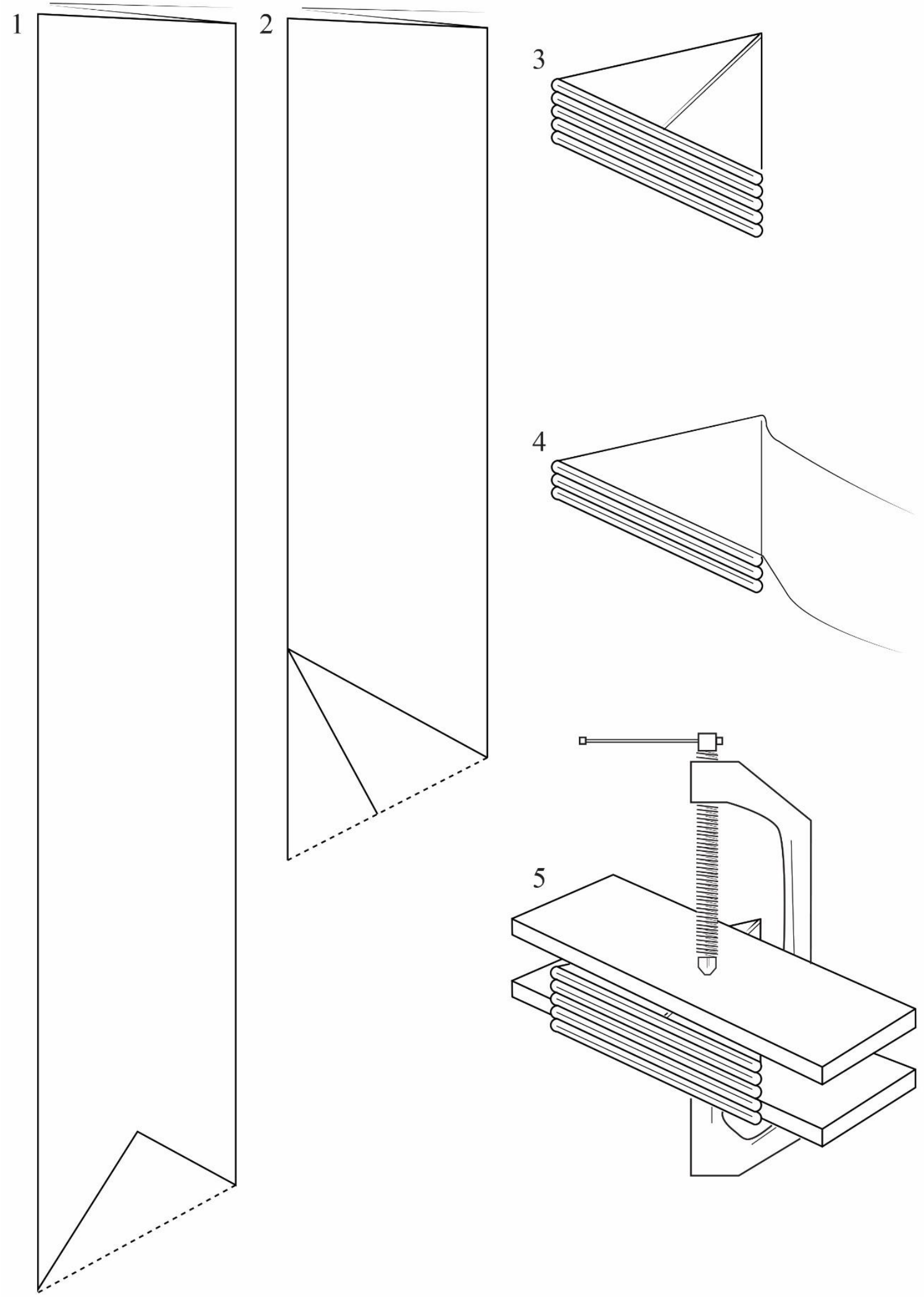

Fig. 3. Illustrated diagram showing Shibori technique used to create sample C. 



Fig. 4. Illustrated diagram showing Shibori technique used to create sample D. 


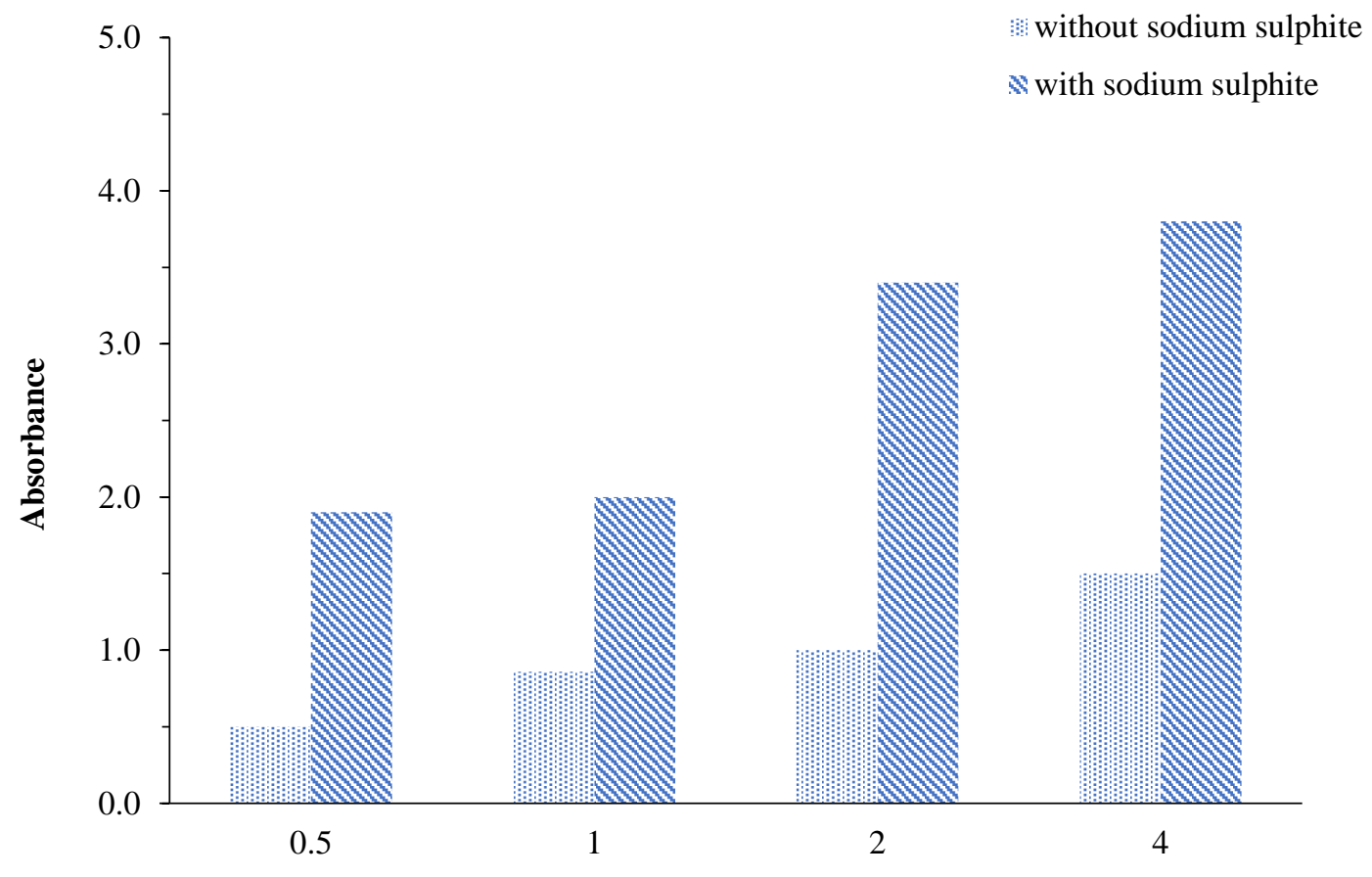

Treatment time (h)

Fig. 5. The absorption at $600 \mathrm{~nm}$ of enzyme treatment liquors of pre-dyed wool/polyester samples treated with Esperase or Esperase with the addition of sodium sulphite. 


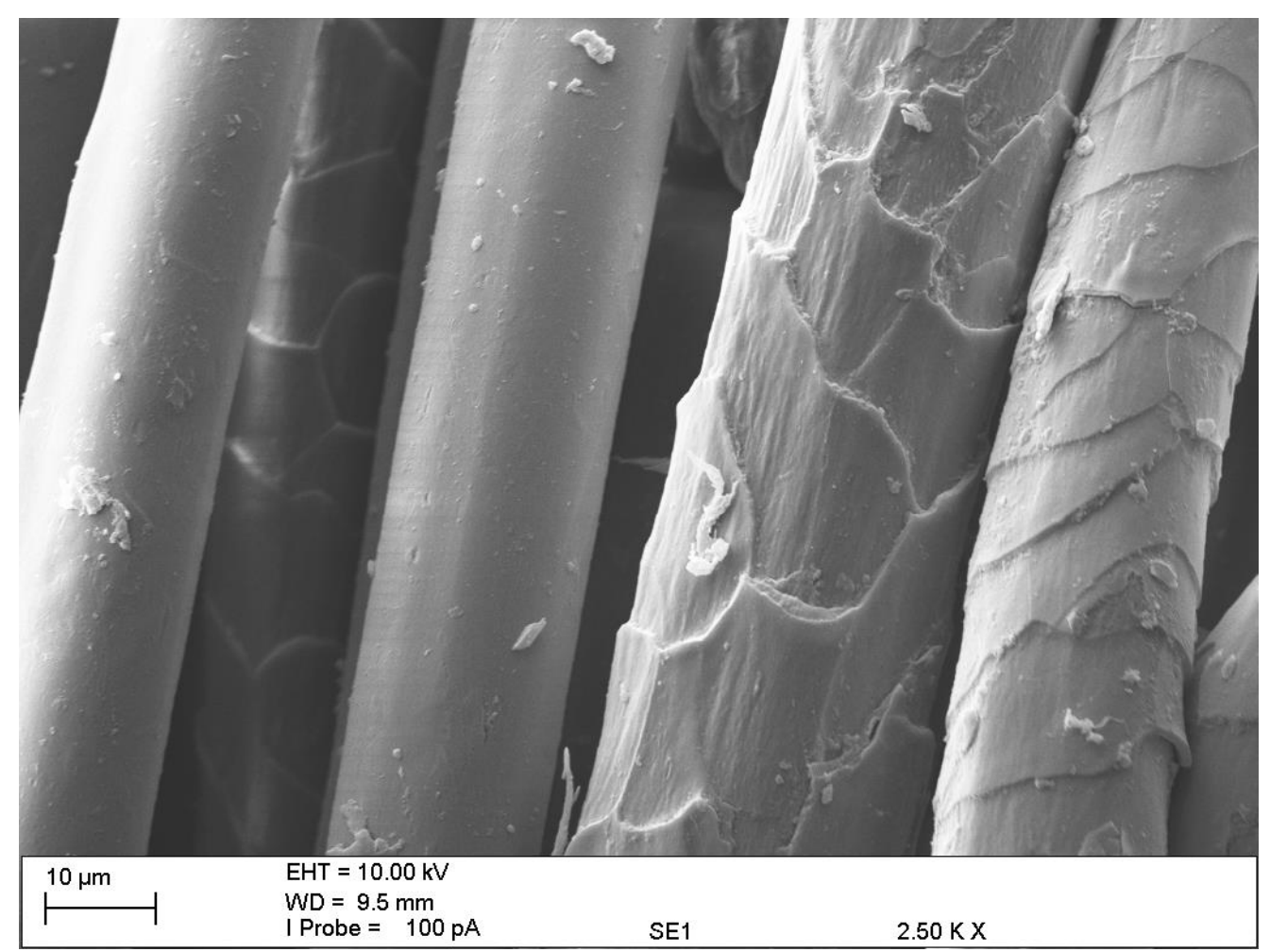

Fig. 6. SEM image of untreated wool/polyester fabric. 


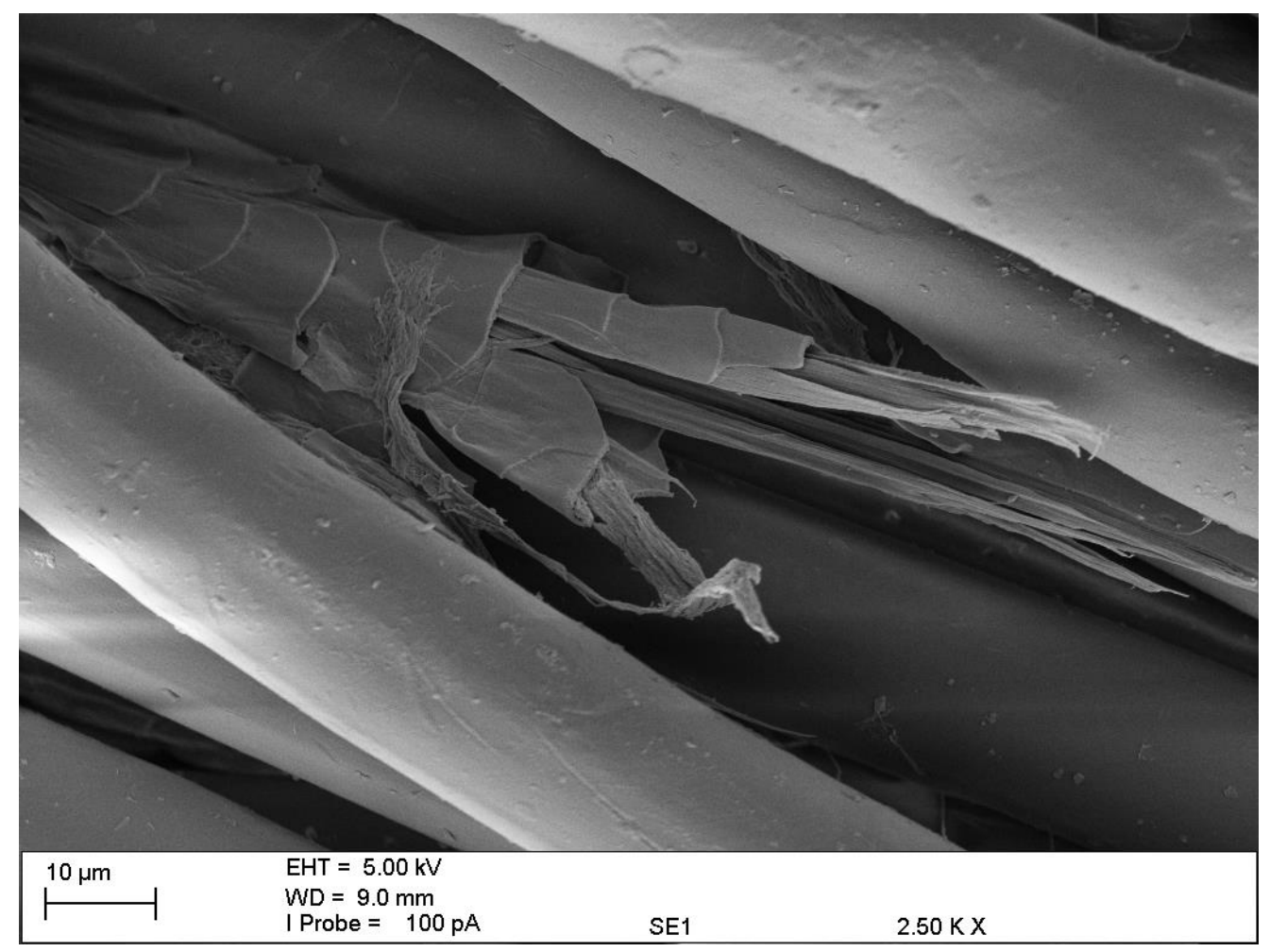

Fig. 7. SEM image of wool/polyester sample enzyme treated in the presence of sodium sulphite. 

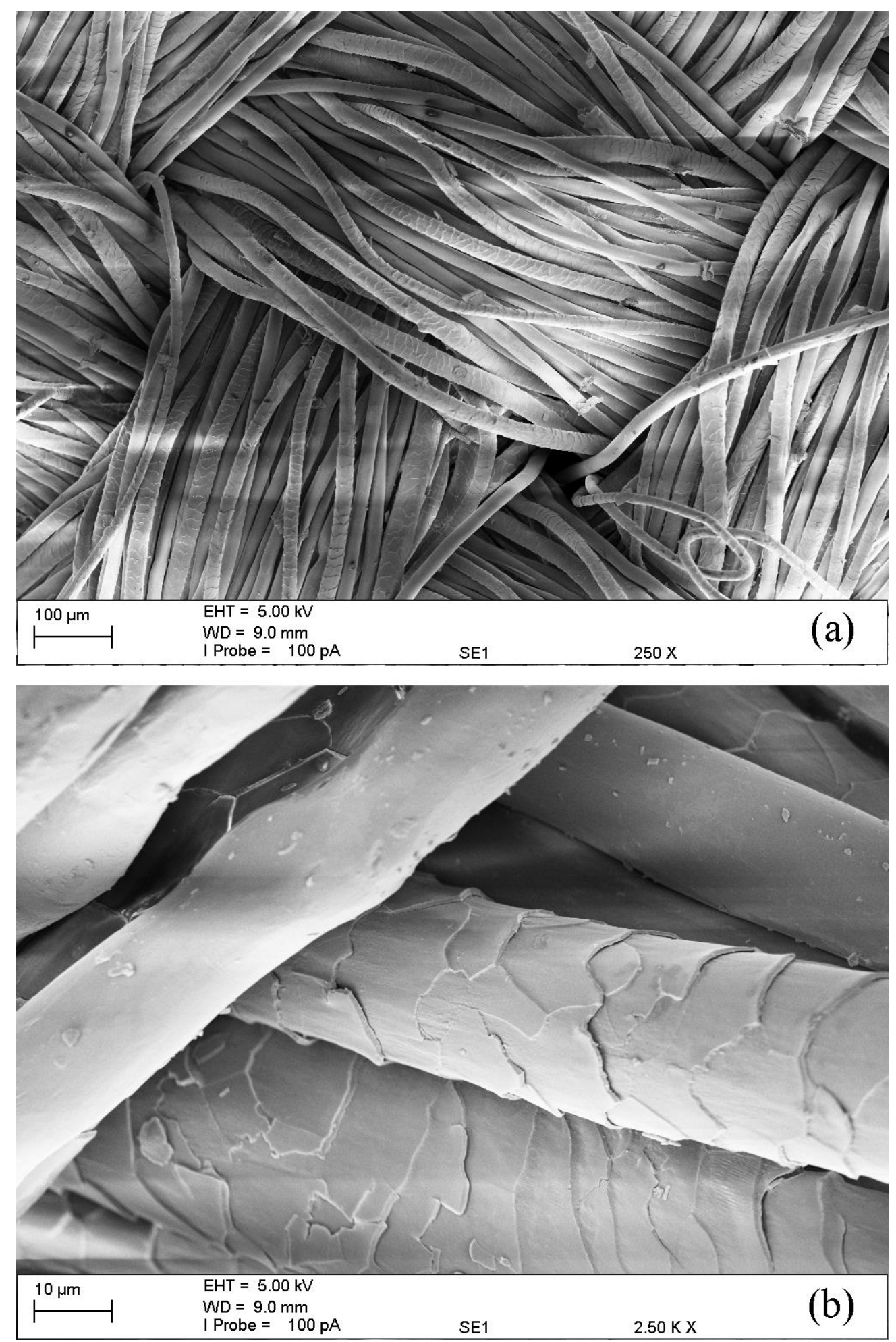

Fig. 8. SEM images of wool/polyester control sample treated in the absence of Esperase at magnification of (a) 250x and (b) 2500x. 

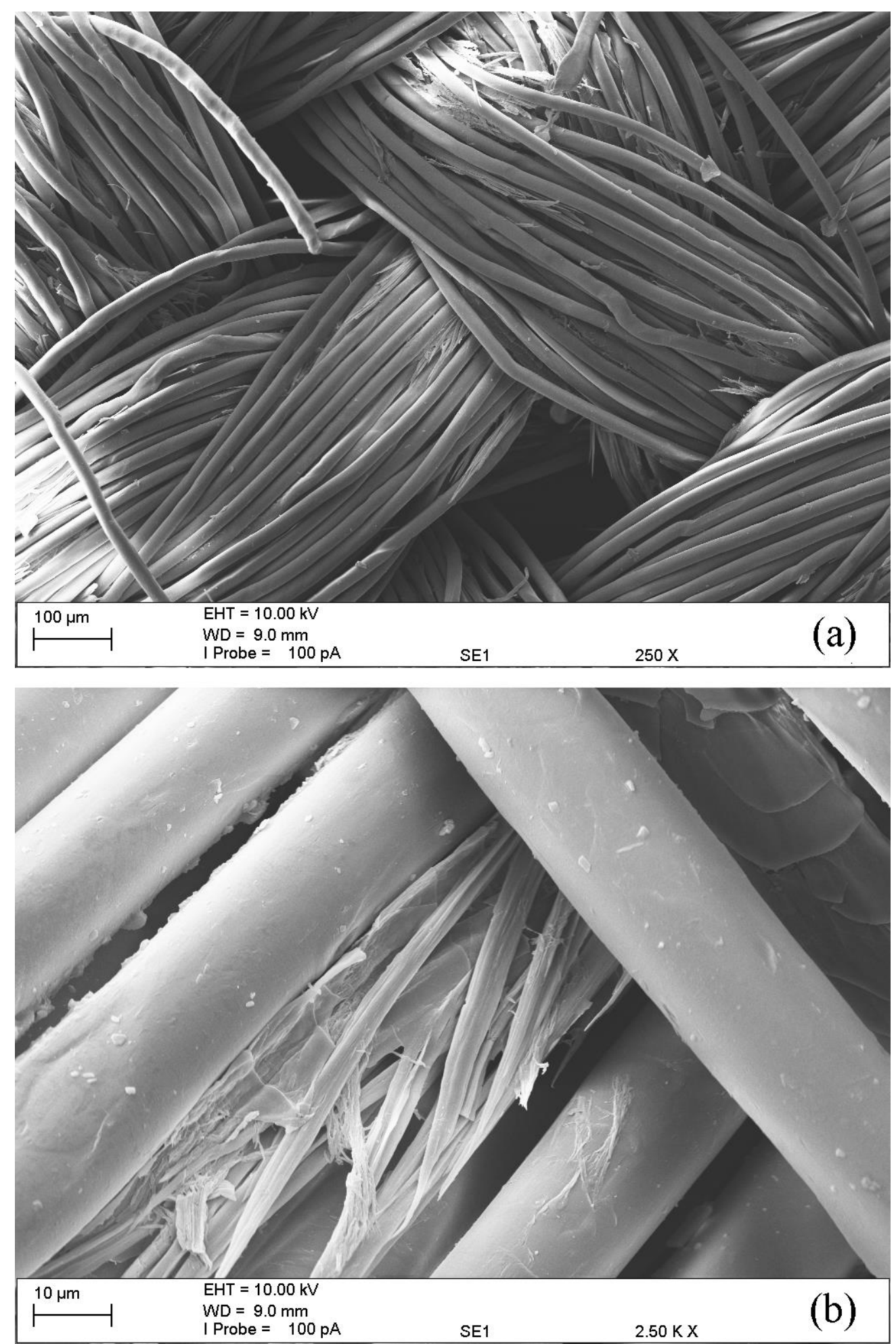

Fig. 9. SEM images of wool/polyester sample treated with Esperase at magnification of (a) $250 x$ and (b) 2500x. 


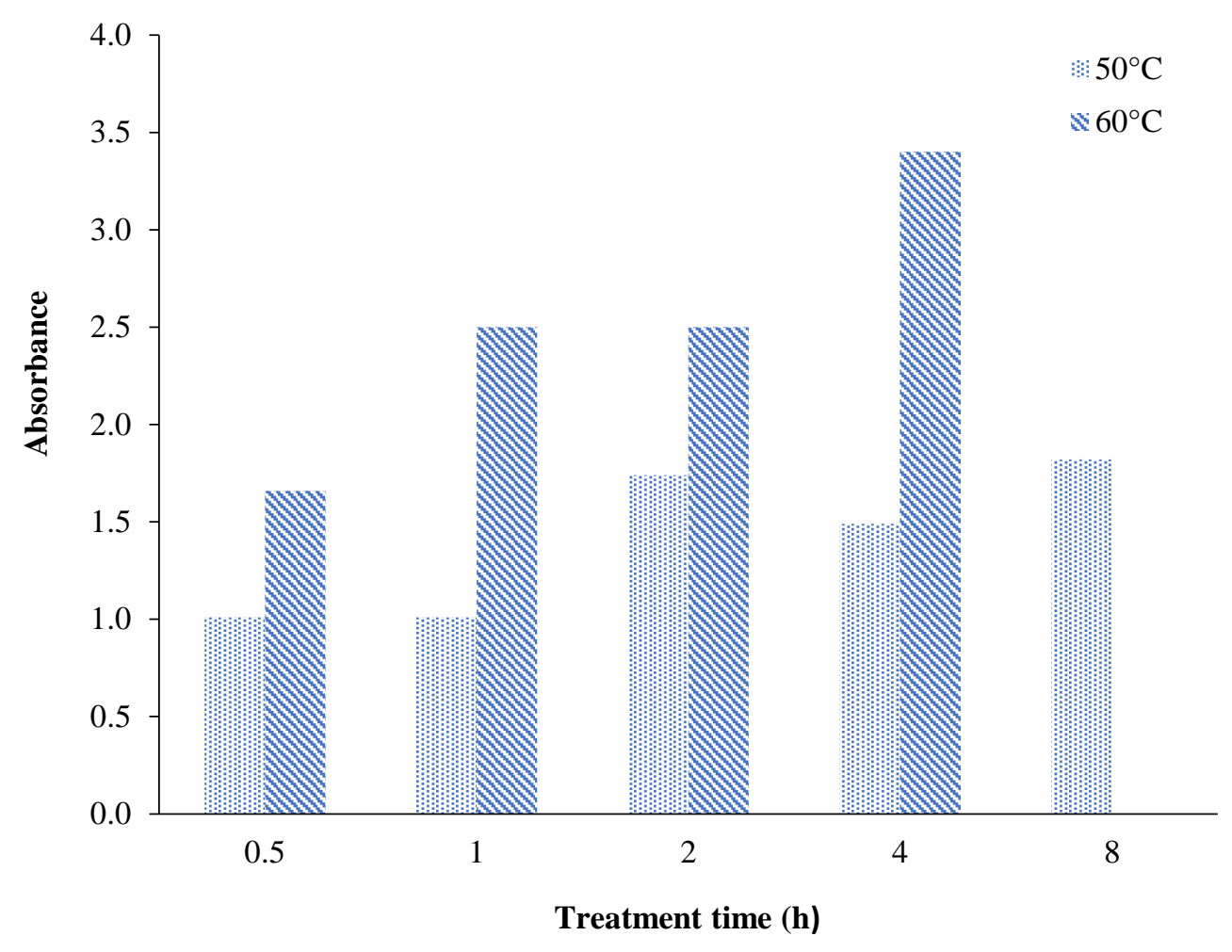

Fig. 10. The absorption at $600 \mathrm{~nm}$ of enzyme treatment liquors of pre-dyed wool/polyester samples treated using $50^{\circ} \mathrm{C}$ and $60^{\circ} \mathrm{C}$. 


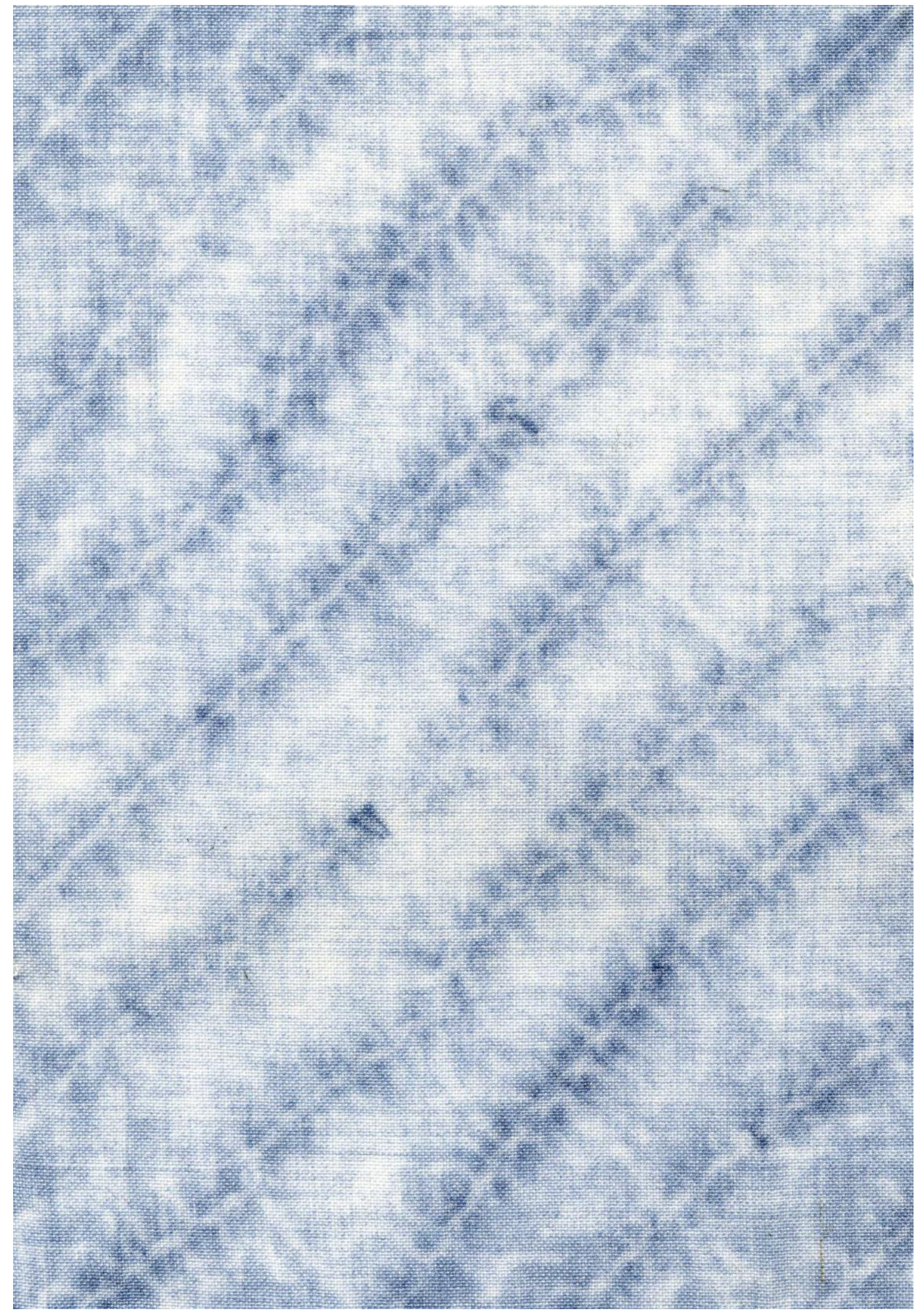

Fig. 11. Sample A, wool/polyester fabric, coloured pattern design generated by stitch resist method illustrated in Fig. 1 with protease processing. 


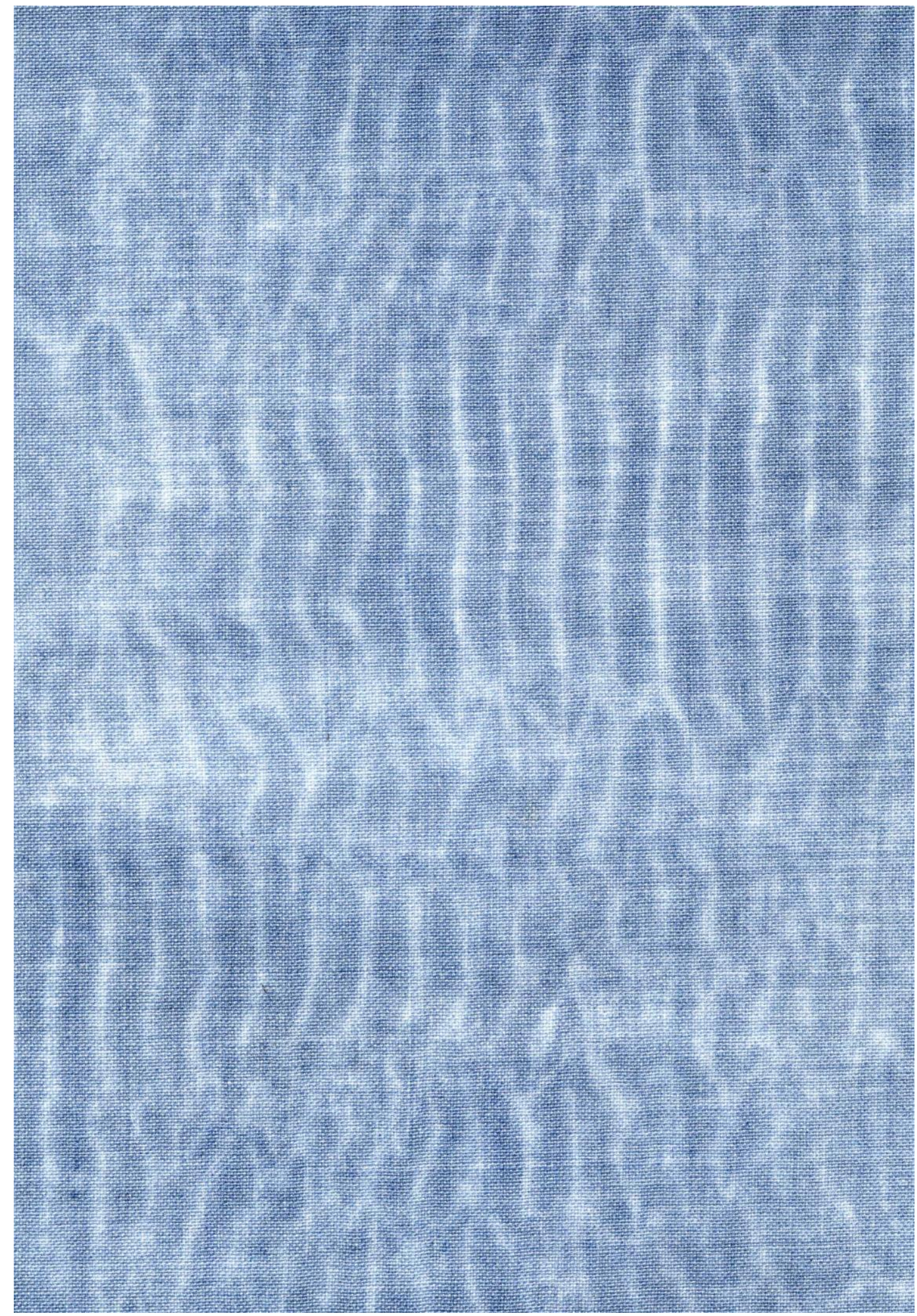

Fig. 12. Sample B, wool/polyester fabric, coloured pattern design generated by stitch resist method illustrated in Fig. 2 with protease processing. 


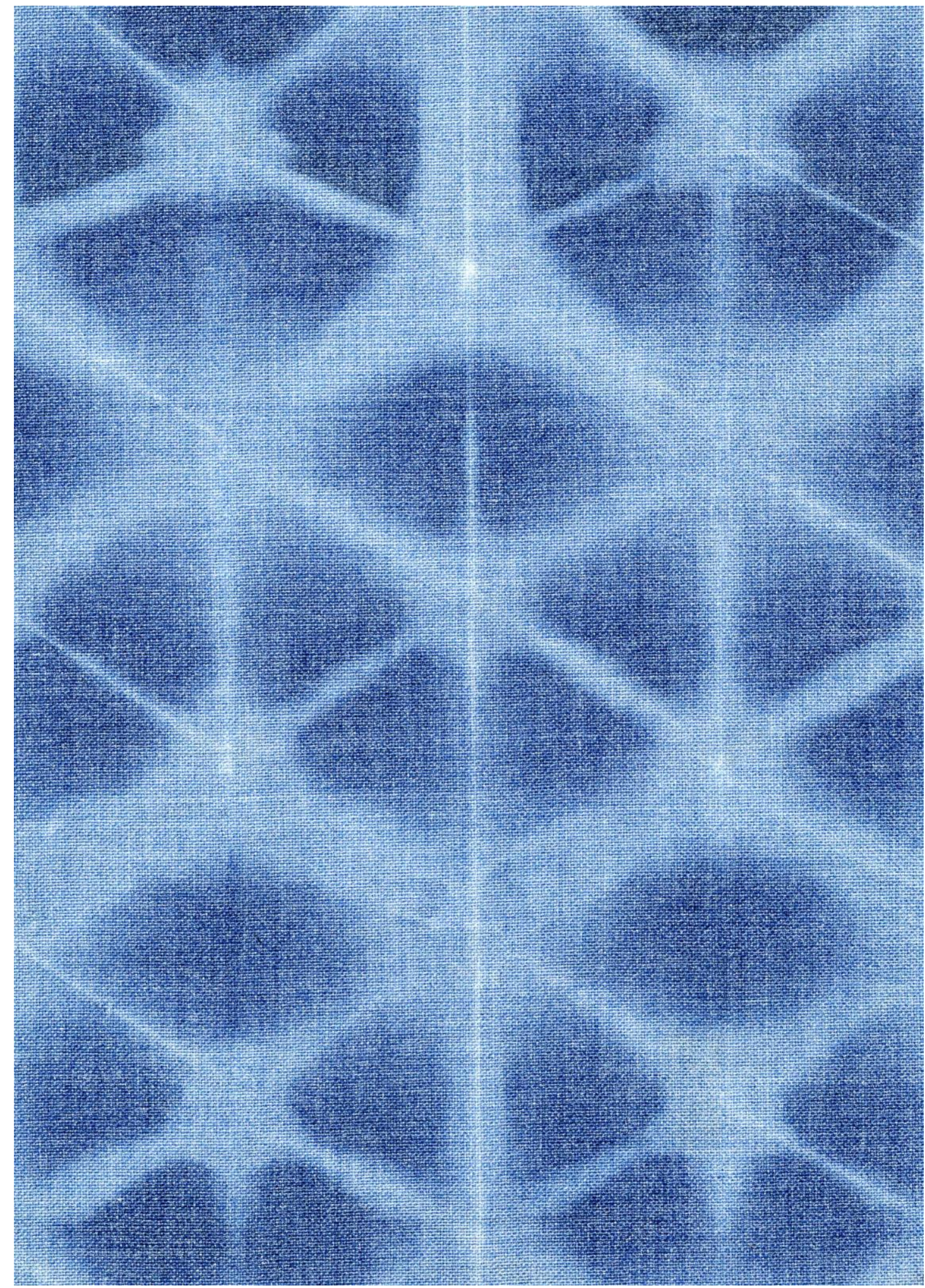

Fig. 13. Sample C, wool/polyester fabric, coloured pattern design generated by clamping resist method illustrated in Fig. 3 with protease processing. 


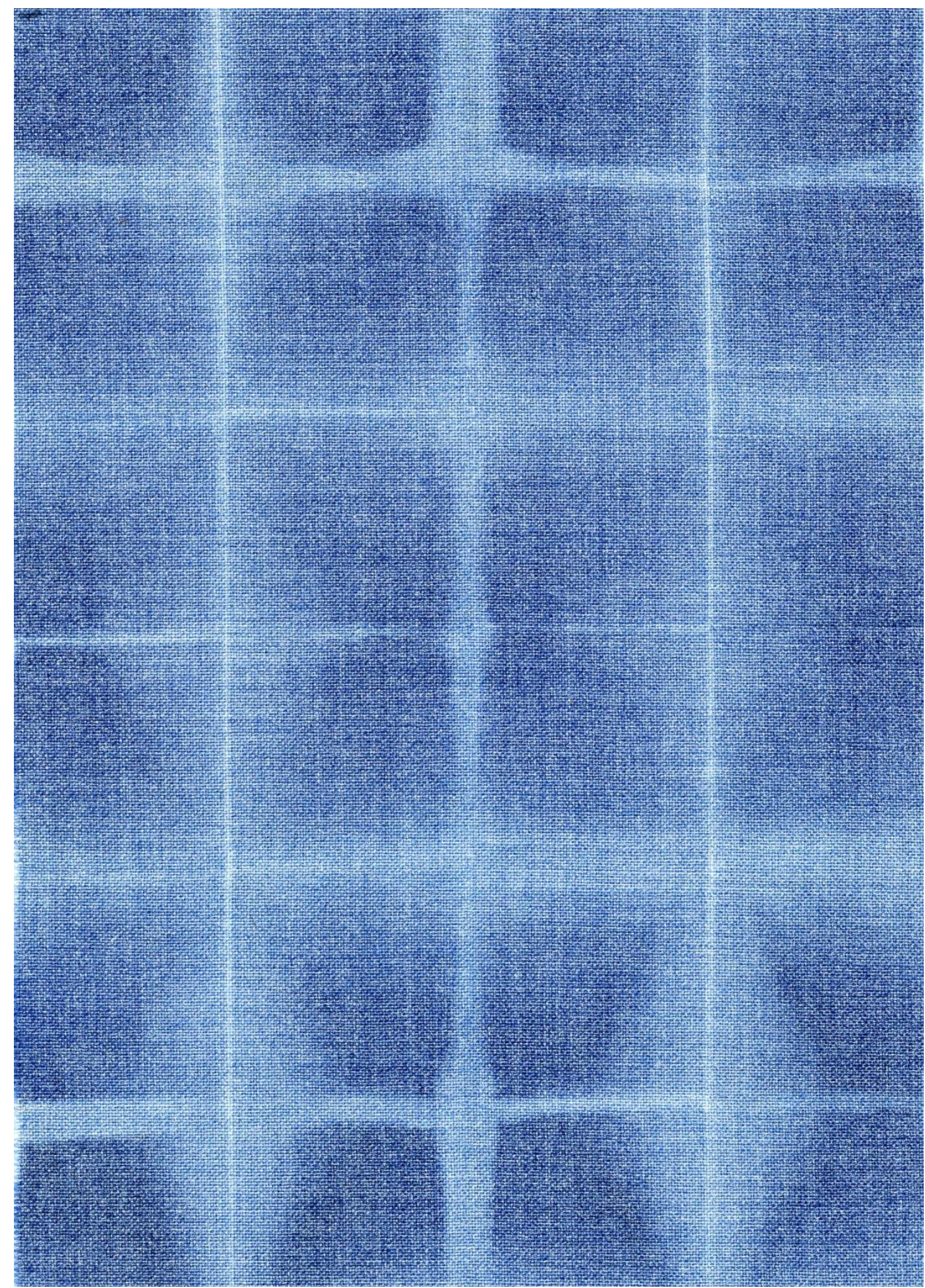

Fig. 14. Sample D, wool/polyester fabric, coloured pattern design generated by clamping resist method illustrated in Fig. 4 with protease processing. 


\section{Table 1}

Weight loss and colour measurements observed after treatment of pre-dyed wool/polyester samples with Esperase or Esperase with the addition of sodium sulphite at $50^{\circ} \mathrm{C}$.

\begin{tabular}{|c|c|c|c|c|c|c|c|c|c|}
\hline $\begin{array}{c}\text { Enzyme } \\
\text { conc. } \\
(\mu \mathrm{L} / 100 \\
\mathrm{mL})\end{array}$ & $\begin{array}{l}\text { Sodium } \\
\text { sulphite } \\
\text { (M) }\end{array}$ & $\begin{array}{l}\text { Treatment } \\
\text { time } \\
\text { (h) }\end{array}$ & $\begin{array}{l}\text { Fabric } \\
\text { sample } \\
\text { after } \\
\text { treatment }\end{array}$ & $\begin{array}{l}\text { Weight } \\
\text { loss } \\
(\%)\end{array}$ & $L^{*}$ & $a^{*}$ & $b^{*}$ & $\Delta E$ & $\begin{array}{c}K / S \\
(620 \mathrm{~nm})\end{array}$ \\
\hline 0 (Control) & 0 & 4.0 & & 0.0 & 34.8 & -1.2 & -8.9 & - & 5.9 \\
\hline 100 & 0 & 0.5 & & 0.0 & 34.6 & -1.2 & -9.0 & 0.4 & 6.0 \\
\hline 100 & 0 & 1.0 & & 0.0 & 34.9 & 1.3 & -9.2 & 0.6 & 6.0 \\
\hline 100 & 0 & 2.0 & & 0.5 & 35.9 & -1.5 & -9.6 & 1.2 & 5.6 \\
\hline 100 & 0 & 4.0 & & 2.0 & 36.9 & -2.0 & -10.5 & 2.6 & 5.4 \\
\hline 100 & 0.05 & 0.5 & & 4.5 & 36.8 & -1.9 & -10.2 & 2.4 & 5.3 \\
\hline 100 & 0.05 & 1.0 & & 5.5 & 37.6 & -2.2 & -10.7 & 3.4 & 5.2 \\
\hline 100 & 0.05 & 2.0 & & 12.0 & 40.5 & -3.1 & -11.7 & 6.5 & 4.4 \\
\hline 100 & 0.05 & 4.0 & & 20.0 & 47.2 & -4.3 & -13.4 & 13.4 & 3.0 \\
\hline
\end{tabular}


Table 2

Weight loss and colour measurements observed after enzyme treatment of pre-dyed wool/polyester samples with increased concentrations of Esperase at $50^{\circ} \mathrm{C}$.

\begin{tabular}{|c|c|c|c|c|c|c|}
\hline \multirow[b]{2}{*}{$\begin{array}{c}\text { Fabric } \\
\text { samples }\end{array}$} & \multicolumn{3}{|c|}{ Enzymatic treatment } & \multirow{2}{*}{$\begin{array}{l}\text { Fabric sample } \\
\text { after } \\
\text { treatment }\end{array}$} & \multirow[b]{2}{*}{$\begin{array}{l}\text { Weight } \\
\text { loss (\%) }\end{array}$} & \multirow[b]{2}{*}{$\begin{array}{c}K / S \\
(620 \mathrm{~nm})\end{array}$} \\
\hline & $\begin{array}{c}\text { Enzyme } \\
\text { conc. } \\
(\mu \mathrm{L} / 100 \mathrm{~mL})\end{array}$ & $\begin{array}{l}\text { Sodium } \\
\text { sulphite } \\
\text { (M) }\end{array}$ & $\begin{array}{l}\text { Treatment } \\
\text { time } \\
\text { (h) }\end{array}$ & & & \\
\hline \multirow{5}{*}{$\begin{array}{l}\text { Pre-dyed at } \\
5 \% \text { omf }\end{array}$} & Control & - & - & - & - & 5.9 \\
\hline & 200 & 0.05 & 0.5 & & 8.5 & 4.7 \\
\hline & 200 & 0.05 & 1.0 & & 9.5 & 4.7 \\
\hline & 200 & 0.05 & 2.0 & & 25.5 & 2.7 \\
\hline & 200 & 0.05 & 4.0 & & 29.0 & 2.1 \\
\hline \multirow{5}{*}{$\begin{array}{l}\text { Pre-dyed at } \\
2 \% \text { omf }\end{array}$} & Control & - & - & - & - & 5.9 \\
\hline & 200 & 0.05 & 0.5 & & 10.0 & 3.9 \\
\hline & 200 & 0.05 & 1.0 & & 16.5 & 2.9 \\
\hline & 200 & 0.05 & 2.0 & & 30.0 & 1.4 \\
\hline & 200 & 0.05 & 4.0 & & 40.5 & 0.5 \\
\hline
\end{tabular}


Table 3

Weight loss and colour measurements observed after enzyme treatment of pre-dyed wool/polyester samples conducted at $50^{\circ} \mathrm{C}$ and $60^{\circ} \mathrm{C}$.

\begin{tabular}{|c|c|c|c|c|c|c|}
\hline \multicolumn{4}{|c|}{ Enzymatic treatment } & \multirow[b]{2}{*}{$\begin{array}{c}\text { Fabric } \\
\text { sample after } \\
\text { treatment }\end{array}$} & \multirow[b]{2}{*}{$\begin{array}{l}\text { Weight } \\
\text { loss (\%) }\end{array}$} & \multirow[b]{2}{*}{$\begin{array}{c}K / S \\
(620 \mathrm{~nm}\end{array}$} \\
\hline $\begin{array}{l}\text { Enzyme conc. } \\
(\mu \mathrm{L} / 100 \mathrm{~mL})\end{array}$ & $\begin{array}{l}\text { Sodium } \\
\text { sulphite } \\
\text { (M) }\end{array}$ & $\begin{array}{l}\text { Treatment } \\
\text { time } \\
\text { (h) }\end{array}$ & $\begin{array}{c}\text { Treatment } \\
\text { temp. } \\
\left({ }^{\circ} \mathrm{C}\right)\end{array}$ & & & \\
\hline Control & - & - & - & & - & 5.8 \\
\hline 100 & 0.05 & 0.5 & & & 9.0 & 4.4 \\
\hline 100 & 0.05 & 1.0 & & & 12.0 & 3.8 \\
\hline 100 & 0.05 & 2.0 & & & 24.0 & 2.2 \\
\hline & & & 50 & & & \\
\hline 100 & 0.05 & 4.0 & & & 27.5 & 1.4 \\
\hline 100 & 0.05 & 8.0 & & & 35.0 & 0.9 \\
\hline 0 & 0.05 & 8.0 & & & 0.0 & 5.8 \\
\hline 100 & 0.05 & 0.5 & & & 20.5 & 2.2 \\
\hline 100 & 0.05 & 1.0 & & & 25.0 & 1.9 \\
\hline 100 & 0.05 & 2.0 & 60 & & 34.5 & 1.0 \\
\hline 100 & 0.05 & 4.0 & & & 36.5 & 0.9 \\
\hline 0 & 0.05 & 4.0 & & & 0.0 & 5.8 \\
\hline
\end{tabular}




\section{Table 4}

Weight loss and colour measurements observed with enzyme treatments conducted at $60^{\circ} \mathrm{C}$ with increased agitation.

\begin{tabular}{|c|c|c|c|c|c|c|}
\hline \multirow{2}{*}{$\begin{array}{c}\text { Fabric } \\
\text { samples }\end{array}$} & \multicolumn{3}{|c|}{ Enzymatic treatment } & \multirow{2}{*}{$\begin{array}{c}\text { Fabric } \\
\text { sample after } \\
\text { treatment }\end{array}$} & \multirow{2}{*}{$\begin{array}{l}\text { Weight } \\
\text { loss (\%) }\end{array}$} & \multirow{2}{*}{$\begin{array}{c}K / S \\
(620 \mathrm{~nm})\end{array}$} \\
\hline & $\begin{array}{l}\text { Enzyme conc. } \\
(\mu \mathrm{L} / 100 \mathrm{~mL})\end{array}$ & $\begin{array}{l}\text { Sodium sulphite } \\
\text { (M) }\end{array}$ & $\begin{array}{l}\text { Treatment } \\
\text { time }(\mathrm{h})\end{array}$ & & & \\
\hline \multirow{5}{*}{$\begin{array}{l}\text { Pre-dyed } \\
\text { at } 2 \% \text { omf }\end{array}$} & - & - & - & & - & 5.9 \\
\hline & 100 & 0.05 & 0.5 & & 17.5 & 2.7 \\
\hline & 100 & 0.05 & 1.0 & & 25.0 & 2.1 \\
\hline & 100 & 0.05 & 2.0 & & 34.0 & 1.1 \\
\hline & 100 & 0.05 & 4.0 & & 38.5 & 0.6 \\
\hline
\end{tabular}




\section{Table 5}

Tensile properties of untreated and enzyme treated wool/polyester fabrics.

\begin{tabular}{ccccc}
\hline & \multicolumn{2}{c}{ Warp } & \multicolumn{2}{c}{ Weft } \\
\cline { 2 - 5 } Fabric samples & $\begin{array}{c}\text { Load at break } \\
(\mathrm{N})\end{array}$ & $\begin{array}{c}\text { Tensile strain } \\
\text { (Extension) } \\
\text { Break (\%) }\end{array}$ & $\begin{array}{c}\text { Load at break } \\
(\mathrm{N})\end{array}$ & $\begin{array}{c}\text { Tensile strain } \\
\text { (Extension) at } \\
\text { Break (\%) }\end{array}$ \\
\hline Untreated & 632.7 & 39.4 & 583.9 & 30.8 \\
\hline Enzyme Treated & 450.8 & 30.3 & 350.9 & 25.7 \\
\hline Loss (Difference) \% & 28.8 & 23.0 & 39.9 & 16.7 \\
\hline
\end{tabular}

